\title{
Article
}

\section{Southern African large frame Indigenous Veld Goat and Boer Goat wether and buck tenderness and colour of six muscles}

\author{
Gertruida L. van Wyk ${ }^{1}$, Louwrens C. Hoffman ${ }^{1,2}$, Phillip E. Strydom ${ }^{1}$ and Lorinda Frylinck ${ }^{3 *}$ \\ 1 Department of Animal Sciences, University of Stellenbosch, Private Bag X1, Matieland, Stellenbosch 7602, \\ South Africa \\ 2 Centre for Nutrition and Food Sciences, Queensland Alliance for Agriculture and Food Innovation (QAAFI), \\ The University of Queensland, Digital Agricultural Building. 8115. Office 110. Gatton 4343. Queensland, \\ Australia \\ 3 Agricultural Research Council - Animal Production, Private Bag X2, Irene 0062, South Africa \\ * Correspondence: lorinda@arc.agric.za; Tel.: (+27-12-672-9385)
}

Simple Summary: The study describes the meat tenderness and colour attributes of six muscles (Longissimus thoracis et lumborum (LTL), Semimembranosus (SM), Biceps femoris (BF), Supraspinatus (SS), Infraspinatus (IS), Semitendinosus (ST)) from same-aged young wethers and bucks of Boer Goat (BG) and Indigenous Veld Goats (IVG: Cape Speckled and the Cape Lob Ear). IVG is a collective name for the eco-types conserved by the Indigenous Veld Goat Society of South Africa. Muscle tenderness and colour characteristics differed more between wethers and bucks than between IVG and BG. Large frame IVG bucks and wethers produced very similar meat tenderness, juiciness and colour characteristics as the BG bucks and wethers indicating them to be just as suited for meat production. The wethers' meat with its increased intramuscular fat in all six muscles tested would satisfy the consumer segment that prefer juicier and flavorsome meat. Knowledge of muscle characteristics of goat carcasses will help the development of the formal commercial market for goat meat that would benefit smallholder farmers who typically produce most of the goats in the world.

\begin{abstract}
Meat tenderness, water holding capacity (WHC) and colour attributes of six muscles (Longissimus thoracis et lumborum (LTL), Semimembranosus (SM), Biceps femoris (BF), Supraspinatus (SS), Infraspinatus (IS), Semitendinosus (ST)) from large frame Indigenous Veld Goats (IVG) and Boer Goats (BG) were studied. Weaner male Boer Goats (BG; $\mathrm{n}=18 ; 10$ bucks and 8 wethers) and large frame Indigenous Veld Goats (IVG; $n=19 ; 9$ bucks and 10 wethers) were raised on hay and natural grass, and on a commercial pelleted diet to a live weight of $30-35 \mathrm{~kg}$. All goats were slaughtered at a commercial abattoir and the dressed carcasses chilled at $4^{\circ} \mathrm{C}$ within 1-hour post-mortem. The muscles were dissected from both sides 24 -hours post-mortem and aged for 1-day and 4-days. Variations in meat characteristics such as ultimate $\mathrm{pH}, \mathrm{WHC}$, percentage purge, myofibril fragment length, intramuscular fat, connective tissue characteristics, and Warner-Bratzler shear force. Bucks had higher $\mathrm{L}^{*}$ and Hue-angle values, whereas wethers had increased $\mathrm{a}^{*}$ and Chroma values. The muscle baseline-data will allow informed decisions to support muscle-specific marketing strategies, which may be used to improve consumer acceptability of chevon.
\end{abstract}

Keywords: Cape Lob Ear, Cape Speckled, meat goat breeds, meat tenderness, meat colour, collagen, chevon

\section{Introduction}

Indigenous Veld Goats (IVG) are a group of specific pure-bred indigenous eco-types represented by the IVG-Association that define specific standards that a goat must adhere to before it can be classified as one of the eco-types such as the Cape Lob Ear and the Cape Speckled goats [1]. Both of these eco-types have large frames and can compete with the Boer Goat (BG) in terms of meat yield [2], whilst also having additional advantages such as adaptability to harsh climates and disease resistance [3]. The increasing global 
human population and the threat of global warming, makes it important to promote the production of goat meat (chevon) from adapted eco-types such as the IVG. Although chevon is popular amongst the larger population of southern Africa, chevon is not available on the commercial shelves in South Africa, the major reason being that there are insufficient commercial slaughter numbers to ensure a constant supply to the commercial retail market. Although southern Africa has relatively large numbers of meat goats (703,892 head) [4], most are produced in the informal sector and traded within this sector thereby making it challenging obtaining official statistics of the volumes of goat meat produced and traded. Available goats are either sold alive for traditional slaughtering practices or exported to Middle Eastern and Asian countries. Small and emerging southern African farmers are interested in IVGs as they do not require intensive management to be productive. For chevon, quality fresh meat is the most economically profitable, however the scientific knowledge on meat quality of these breed types is scarce, compared to that of the well-known "improved" BG breed and the non-defined "indigenous" goats that are usually used in comparison studies $[5,6,7,8,9,10]$.

The term "meat quality" includes many attributes, of these, texture, juiciness and colour are important attributes to consumers, with texture the most important. Tenderness and mechanical properties of meat are influenced by the connective tissue, myofibrils and their interactions which differ between muscles [11, 12]. Compared to sheep and cattle, knowledge of the meat quality of BG and large frame Indigenous Veld Goats (IVG, Cape Speckled and the Cape Lob Ear) of South Africa is limited due to a previous lack of interest. The goat carcass consists of over a hundred different muscles with different properties, which affect processing characteristics and could influence consumer acceptability [13]. There has been a continued trend in the retail sector to separate muscles, based on perceived connective tissue characteristics, to better market them and apply the knowledge in terms of the users' requirements. Notable studies on the physical and compositional traits of BG muscles have been conducted over the years [7]. These range from carcass measurements and commercial yields [14], cooking and juiciness related quality characteristics [15], including studies to understand the impact of carcass handling on the texture, mainly determined by the Warner-Bratzler shear force (WBSF) on different muscles $[8,9,16,17]$. Most studies evaluating chevon are conducted on the Longissimus thoracis et lumborum (LTL) and Semimembranosus (SM) muscles in terms of tenderness and sensory quality attributes $[5,6,9,10]$. To establish a baseline for IVG eco-types, this paper focuses on the effect of breed (IVG vs. BG) and sex (bucks and wethers) on: ultimate muscle $\mathrm{pH}\left(\mathrm{pH}_{\mathrm{u}}\right)$, percentage purge, water holding capacity (WHC), Warner Bratzler shear force (WBSF), myofibril fragment length (MFL), intra muscular fat (IMF), collagen characteristics, and meat colour (CIE L* $\mathrm{a}^{*}, \mathrm{~b}^{*}$, Chroma and Hue-angle), in six different muscles (i.e. Longissimus thoracis et lumborum (LTL), Semimembranosus (SM), Biceps femoris (BF), Supraspinatus (SS), Infraspinatus (IS), and Semitendinosus (ST)) to establish baselines for these eco-types. 


\section{Materials and Methods}

\subsection{Animal and experimental design}

This research was approved by the Agricultural Research Council - Animal Production (ARC-AP) Ethics Committee (ref no. APIEC16/021). Weaner Boer Goats (BG; $\mathrm{n}=$ 18; 10 bucks and 8 wethers) and large frame Indigenous Veld Goats (IVG; $n=19 ; 9$ bucks and 10 wethers) were purchased from commercial breeders at three months of age (17 kg on average for IVG and $20 \mathrm{~kg}$ on average for BG). When bought, the commercial breeder had already castrated the male animals on the farm. The animals were reared at the Small Stock Section of the ARC-AP facility situated in Irene, in the Gauteng province of South Africa where they grazed a natural grass diet supplemented with hay ad libitum and an average of $250 \mathrm{~g}$ commercial "Ram, lamb and ewe - 13" pellets (protein $130 \mathrm{~g} / \mathrm{kg}$, fat 25 $70 \mathrm{~g} / \mathrm{kg}$, fibre $150 \mathrm{~g} / \mathrm{kg}$, moisture $120 \mathrm{~g} / \mathrm{kg}$, calcium $15 \mathrm{~g} / \mathrm{kg}$, phosphorus $3 \mathrm{~g} / \mathrm{kg}$, urea 10 $\mathrm{g} / \mathrm{kg}$; Meadow Feeds, Lanseria, Gauteng, South Africa) per day per animal. The goats spent on average 6 to 8 months until they attained a live weight (LW) of between 30 and $35 \mathrm{~kg}$. After weighing (LW), the goats were transported for $3 \mathrm{~km}$ to the abattoir of the ARC-AP on the day of slaughter. The experimental design is presented in Figure 1 and has been described in more detail in [2]. The carcasses were subjected to electrical stimulation (ES - 20 seconds, 400 Volts peak, $5 \mathrm{~ms}$ pulses at 15 pulses/second), 10 minutes after stunning and exsanguination where after all the carcasses were placed in the chiller at $4^{\circ} \mathrm{C}$ within 60 minutes post-mortem. After chilling $\left(24\right.$ hours, $\left.<4^{\circ} \mathrm{C}\right)$, the carcasses were removed from the chiller and the specific muscles removed from both sides of the carcass and cut into various steaks for the different meat quality analyses (Figure 2). Temperature and $\mathrm{pH}$ values were measured 24 hours post-mortem $\left(\mathrm{pH}_{\mathrm{u}}\right)$ on the same chilled muscles used for colour measurement with a calibrated Crison pH25 meter (Crison Instruments, Barcelona, Spain).

Raised at ARC-AP (diet as specified under Methods) to a LW of between 30 to $35 \mathrm{~kg}$ (age 9 to 12 months)

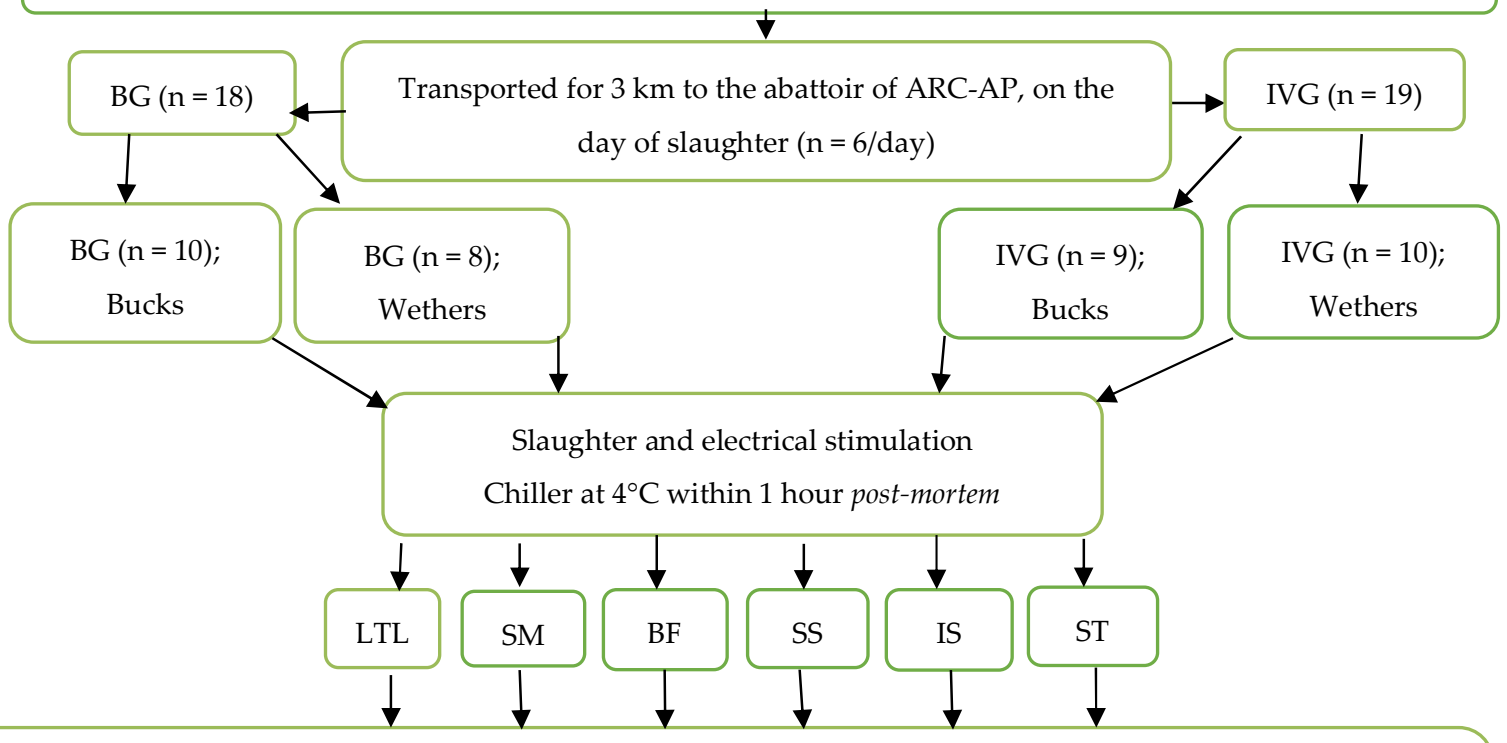

Temperature and $\mathrm{pH}$ (1 day post-mortem); $\mathrm{WHC}=$ water holding capacity ( 1 and 4 days post-mortem); \% purge; WBSF $=$ Warner-Bratzler shear force $(1$ and 4 days post-mortem $) ;$ MFL = myofibril fragment length $(1$ and 4 days post-mortem); IMF = \% intra muscular fat collagen (total and soluble) analysis and meat colour (CIE, $\mathrm{L}^{*} \mathrm{a}^{*} \mathrm{~b}^{*}$ ) 
Figure 1. Experimental design to evaluate the effect of breed; large frame Indigenous Veld Goats (IVG, Cape Speckled and Cape Lob Ear) and Boer Goats (BG) of southern Africa, on tenderness factors, colour attributes and connective tissue characteristic of Longissimus thoracis et lumborum (LTL), Semimembranosus (SM), Biceps femoris (BF), Supraspinatus (SS), Infraspinatus (IS), and Semitendinosus (ST)). ARC-AP = Agricultural Research Council - Animal Production, Irene, South Africa.

LTL

Anterior end

\begin{tabular}{|l|}
\hline Location 1 \\
\hline Location 1 \\
\hline Location 1 \\
\hline Location 2 \\
\hline Location 2 \\
\hline Location 2 \\
\hline Location 2 \\
\hline Location 2 \\
\hline Location 2 \\
\hline Location 2 \\
\hline Location 2 \\
\hline Location 2 \\
\hline Location 2 \\
\hline Location 2 \\
\hline Location 2 \\
\hline Location 3 \\
\hline Location 3 \\
\hline
\end{tabular}

Posterior end

SS

Ventral end

\begin{tabular}{|l|}
\hline Location 1 \\
\hline Location 1 \\
\hline Location 2 \\
\hline Location 2 \\
\hline Location 2 \\
\hline Location 3 \\
\hline
\end{tabular}

Dorsal end
SM
Proximal end

\begin{tabular}{|l|}
\hline Location 1 \\
\hline Location 1 \\
\hline Location 2 \\
\hline Location 2 \\
\hline Location 2 \\
\hline Location 3 \\
\hline
\end{tabular}

Distal end

IS

Ventral end

\begin{tabular}{|l|}
\hline Location 1 \\
\hline Location 1 \\
\hline Location 2 \\
\hline Location 2 \\
\hline Location 2 \\
\hline Location 2 \\
\hline Location 2 \\
\hline Location 3 \\
\hline
\end{tabular}

Dorsal end
BF

Proximal end

\begin{tabular}{|l|}
\hline Location 1 \\
\hline Location 1 \\
\hline Location 1 \\
\hline Location 2 \\
\hline Location 2 \\
\hline Location 2 \\
\hline Location 2 \\
\hline Location 2 \\
\hline Location 2 \\
\hline Location 3 \\
\hline Location 3 \\
\hline
\end{tabular}

Distal end

ST

Proximal end

\begin{tabular}{|l|}
\hline Location 1 \\
\hline Location 1 \\
\hline Location 2 \\
\hline Location 2 \\
\hline Location 2 \\
\hline Location 3 \\
\hline
\end{tabular}

Distal end
Figure 2. Sampling locations of the six different muscles (i.e., Longissimus thoracis et lumborum (LTL), Semimembranosus (SM), Biceps femoris (BF), Supraspinatus (SS), Infraspinatus (IS), and Semitendinosus (ST)). Left side of carcass for 1 day samples for location 1 (meat colour (CIE, L*a* ${ }^{*}$ ), water holding capacity (WHC), myofibril fragment length (MFL), location 2 (Warner-Bratzler shear force (WBSF)) and location 3 (collagen (total and soluble) analysis); Right side of carcass for 4 days samples for location 1 (meat colour (CIE, $\mathrm{L}^{*} \mathrm{a}^{*} \mathrm{~b}^{*}$ ), water holding capacity (WHC), myofibril fragment length (MFL)), location 2 (Warner-Bratzler shear force (WBSF)) and location 3 (collagen (total and soluble) analysis, proximate analysis). Proximal = nearest the vertebral column. Each horizontal section represents a $2.0 \mathrm{~cm}$-thick steak. 


\subsection{Laboratory analysis}

For the chemical and the physical analyses, samples were taken from the various locations of the six muscles Longissimus thoracis et lumborum (LTL), Semimembranosus (SM), Biceps femoris (BF), Supraspinatus (SS), Infraspinatus (IS), and Semitendinosus (ST) as described in Figure 2. Analyses were either conducted on the fresh samples (purge loss, water holding capacity (WHC), chemical and meat colour analyses) or on vacuum packed frozen $\left(-20^{\circ} \mathrm{C}\right)$ and then defrosted $\left(4^{\circ} \mathrm{C}, 24\right.$ hours $)$ samples such as Warner-Bratzler shear force (WBSF).

\subsubsection{Purge and water holding capacity (WHC)}

Purge percentage was measured using a $10 \mathrm{~mm}$ thick slice of the six different muscles (LTL, SM, BF, SS, IS, and ST), vacuumed and aged for 4 days at $4^{\circ} \mathrm{C}$. The specific muscles were weighed before and after storage and the weight difference indicated as purge loss percentage. Water holding capacity (WHC) of the six fresh muscles were determined using the filter paper press method [18]. Briefly, 400 to $500 \mathrm{mg}$ meat sample was placed on filter paper (Whatman 4), contained between two Perspex plates. Constant pressure was applied using a hand-operated screw for 5 minutes. The borders of meat and fluid expressed were marked out and their areas measured using a video image analyser (Soft Imaging System, Olympus Japan), according to [19]. Water holding capacity was expressed as a ratio of meat area to fluid area.

\subsubsection{Warner-Bratzler shear force (WBSF)}

The frozen vacuumed packed muscle samples (LTL, SM, BF, SS, IS, and ST) were placed in a cold room at $4^{\circ} \mathrm{C}$ to thaw for 24 hours before cooking. Whole cuts were prepared according to an oven-broiling method (dry heat cooking) using direct radiant heat [20]. Calibrated electric ovens (Mielé ovens, model H217, Miele \& Cie. KG, Gütersloh, Germany) were set on "broil" 10 minutes prior to cooking at $160^{\circ} \mathrm{C}$. The samples were placed on an oven pan on a rack and broiled for approximately 20 minutes until they reached an internal core temperature of $70^{\circ} \mathrm{C}$. The internal temperature was monitored by placing an iron-constant thermocouple (T-type) (Hand-model Kane-Mane thermometer, Kane International Ltd, Hertfordshire, England) in the approximate geometric centre of each sample. The cooked meat + pan + drip was weighed. The cooked samples were cooled for 2 hours at room temperature $\left(20^{\circ} \mathrm{C}\right)$ before shear force measurement. For shear force measurements, six cylindrical samples (12.5 mm core diameter) were bored parallel to the direction of the muscle fibres. Each core was sheared perpendicular to the myofibrils using a Warner-Bratzler device fitted to an Instron Universal Testing Machine (Model 4301, Instron Ltd, Buckinghamshire, England) at a crosshead speed of 200 $\mathrm{mm} / \mathrm{min}$ with one shear in the centre of each core [21]. The toughness of the meat was the average maximum force $(\mathrm{N})$ required to shear through the cores.

\subsubsection{Myofibril fragmentation length (MFL)}

Samples used for MFL were aged for 1 day and 4 days post-mortem. Sub-samples of ca. $3 \mathrm{~g}$ were taken, blended with a blunt blade in cold potassium phosphate extraction buffer at $4^{\circ} \mathrm{C}$ to arrest any further proteolysis [22], and determined according to [23]. The droplets of extracted MFL solution were mounted on slides, covered with a cover slip, and viewed under a microscope attached to a video image analysis (VIA). One hundred myofibril fragments per sample were examined and measured at a magnification of 40X.

2.2.4. Intra muscular fat (IMF) and collagen characteristics (Total collagen and collagen solubility) 
The intra muscular protein and fat (representing chemical determined intramuscular fat - IMF) were analysed using the procedures of the Association of Official's Analytical Chemist [24] at the ARC-AP Analytical Laboratories. Samples (25 g of homogenized meat) were freeze dried according to method 934.01 [24]. The percentage fat content was determined on $5 \mathrm{~g}$ of freeze dried sample using a 1:2 chloroform/methanol solution for fat extraction (SOXTEC method) as described in [25]. The total nitrogen content in the defatted muscle samples was determined after samples had been digested in a micro Kjeldahl system (Analytical Laboratory ARC-AP). The nitrogen content was multiplied by a factor of 6.25 in order to obtain the protein content of the sample, which was subsequently converted to a value per gram wet meat (method 922.15) [24]. Soluble, insoluble and total collagen were determined in the same fresh samples.

Total collagen content in the six muscles (LTL, SM, BF, SS, IS, and ST) was determined by measuring the total hydroxyl-proline nitrogen content in hydrolysed samples according to a modified method of [26]. Approximately $1 \mathrm{~g}$ of fresh sample was weighed into a hydrolysed tube and mixed with $15 \mathrm{ml}$ of $6 \mathrm{~N} \mathrm{HCl}$. The samples were hydrolysed at $120^{\circ} \mathrm{C}$ for 16 hours, $0.5 \mathrm{~g}$ active carbon was added to each tube, stirred, and filtered through Whatman 4 filter paper. The aliquots were collected in a $100 \mathrm{ml}$ volumetric flask and filled up to a volume with distilled water. An aliquot of $50 \mathrm{ml}$ was used for the determination of total collagen described below.

The solubility of the intramuscular collagen (hydroxy-proline nitrogen content of soluble collagen) was determined according to the method of [27] with some modifications. About $2 \mathrm{~g}$ of fresh sample was stirred in $10 \mathrm{ml}$ of $1 \% \mathrm{NaCl}$. The samples were heated in a shaking water bath at $78^{\circ} \mathrm{C}$ for 60 minutes. The cooled samples were centrifuged at 10,000 RPM for 15 minutes. The supernatants were poured into hydrolysing tubes, marked as soluble. The pellet was poured into another hydrolysing tube and marked insoluble. To each tube, $7.5 \mathrm{ml}$ of $6 \mathrm{~N} \mathrm{HCl}(19.2 \%)$ was added and hydrolysed overnight at $120^{\circ} \mathrm{C}$. The following day, $0.5 \mathrm{~g}$ of active carbon was added to the cooled tubes, stirred, and the homogenates filtered into $50 \mathrm{ml}$ volumetric flasks and filled to the mark with distilled water. Aliquots of $50 \mathrm{ml}$ were used for determination of both soluble and insoluble collagen.

Hydroxy-proline concentrations were determined calorimetrically according to a modified method of [28]. About $1 \mathrm{ml}$ of the final sample was added into the test tubes where $1 \mathrm{ml}$ of $10 \% \mathrm{KOH}$ solution was added (to neutralise the acid in the sample). A blank consisting of $2 \mathrm{ml}$ distilled water was prepared. Standard solutions were prepared containing zero to $7.5 \mu \mathrm{g} / \mathrm{ml}$ and $2 \mathrm{ml}$ hydroxy-proline to create a new standard curve for each analyses session.

To each test tube (including standards and blanks), $1 \mathrm{ml}$ of the oxidant solution (1.41 g Chloramine-T in a $100 \mathrm{ml}, \mathrm{pH} 6.8$ buffer solution consisting of: $26 \mathrm{~g}$ citric acid monohydrate, $14 \mathrm{~g}$ sodium hydroxide, $78 \mathrm{~g}$ Anhydrous sodium acetate and $250 \mathrm{ml}$ propan-1-ol) was added. The tubes were vortexed for 5 seconds and left for 20 minutes at room temperature. After 20 minutes, $1 \mathrm{ml}$ of the colour reagent $(10 \mathrm{~g}$ para-dimethylaminobenzaldehyde, $35 \mathrm{ml}$ perchloric acid solution (60\%), $65 \mathrm{ml}$ propan-2-ol, prepared fresh) was added and the tubes vortexed. The tubes were heated to $62^{\circ} \mathrm{C} \pm 5^{\circ} \mathrm{C}$ for 30 minutes, then vortexed. Thereafter, they were cooled to room temperature (a strong aromatic pink liquid with a white salt residue forms in the tubes). The top transparent pink liquid was pipetted into disposable micro cuvettes and absorbance was read on a spectrophotometer at $558 \mathrm{~nm}( \pm 2 \mathrm{~nm})$. Hydroxy-proline content was determined from the standard addition curve.

Total collagen content was determined by calculating hydroxy-proline nitrogen from hydroxy-proline (MM 131.13 and nitrogen atom number 14.0067). Collagen values were expressed as $\mathrm{mg}$ collagen/g of muscle sample by using the hydroxy-proline conversion of 7.25 and 7.53 for insoluble and soluble collagen respectively [29].

\subsubsection{Minolta meat colour and $p H$ measurements}


Colour of muscle samples (ca. $15 \mathrm{~mm}$ thick) were measured fresh at 1 day and 4 days post-mortem. The meat samples were allowed to bloom for 60 minutes at $\pm 4^{\circ} \mathrm{C}$ before the meat colour values were recorded. A Konica-Minolta $600 \mathrm{~d}$ spectrophotometer (Konica-Minolta Inc. Osaka, Japan) with the software package Spectra Magic NX Pro was used to measure surface D65 at three different positions on the meat samples. Three components were recorded; lightness, $\mathrm{L}^{*}$ (dark [0] to light [100]) and the two chromatic components; $a^{*}$ (green $\left[-60,180^{\circ}\right]$ to red $\left[+60,0^{\circ}\right]$ ) and $b^{*}$ (blue $\left[-60,270^{\circ}\right]$ to yellow $\left[+60,90^{\circ}\right]$ ) which represented the myoglobin levels in the meat [30]. The spectrophotometer configuration consisted of illuminate (A), with an observer angle of $10^{\circ}$ and the spectral component excluded (SCE) after calibration using a white reference [31]. Chroma (saturation index $(S)=\left(a^{* 2}+b^{* 2}\right)^{1 / 2} ;[32]$ and Hue-angle (discolouration) $=\tan ^{-1\left(b^{*} / a^{*}\right)} ;[33]$ were calculated from $a^{*}$ and $b^{*}$ values, Chroma measures colour intensity where the higher values indicate more intense red colour in meat. An increase in Hue-angle between $0^{\circ}$ and $90^{\circ}$ corresponds to a blending of yellowness or less of redness, probably due to metmyoglobin formation in fresh meat.

\subsubsection{Statistical analysis}

The data were subjected to analysis of variance (ANOVA) [34] to test the effect of breeds (BG and IVG), and sex-types (bucks and wethers) on six muscles for the following characteristics; $\mathrm{pH}$ and temperature (24 hours post-mortem, $\mathrm{pH}$ and $\mathrm{Tu}$ ), WHC (1 and 4 days post-mortem), \% DL, WBSF (1 and 4 days post-mortem), MFL ( 1 and 4 days post-mortem), connective tissue characteristics, and meat colour (CIE L*, $\mathrm{a}^{*}, \mathrm{~b}^{*}$, Chroma and Hue-angle, 1 and 4 days post-mortem) [35]. Statistical significance (Fisher's t-test, least significant difference) was calculated at a $5 \%$ level to compare means. $\mathrm{P} \leq 0.05$ was considered statistically significant, although in some instances' data with a $\mathrm{P} \leq 0.1,(10 \%$ level) was considered as a trend worth discussing.

Prior to analyses, a Shapiro-Wilk test for normality was performed on the data [36] and where applicable, outliers (classified as such when the standardized residual for an observation deviated with more than three SDs from the model value) were removed. Where applicable, the closeness of the linear relationships between the measured variables was determined using Pearson' correlation coefficient (r).

\section{Results}

The results for the carcass characteristics of the experimental animals have been described previously [2] and summarised in Table 1

Table 1. Least square means and standard error (SE) of means for carcass characteristics of Boer(BG) and large frame Indigenous Veld (IVG) buck and wether goats (adapted from [2]).

\begin{tabular}{|c|c|c|c|c|c|c|c|}
\hline \multicolumn{8}{|c|}{ Breed } \\
\hline \multirow{3}{*}{$\begin{array}{l}\text { Carcass } \\
\text { characteristics }\end{array}$} & \multicolumn{2}{|r|}{ BG } & \multicolumn{2}{|c|}{ IVG } & \multicolumn{3}{|c|}{ Significance (P - Values) } \\
\hline & Bucks & Wethers & Bucks & Wethers & Breed & Sex & Breed \\
\hline & $\mathrm{n}=\mathbf{1 0}$ & $n=8$ & $\mathrm{n}=9$ & $n=10$ & & & Sex \\
\hline Live weight (kg) & $35.40^{\mathrm{ab}} \pm 4.01$ & $36.13^{a} \pm 3.02$ & $3667^{a} \pm 2.68$ & $32.8^{\mathrm{b}} \pm 2.39$ & 0.293 & 0.118 & 0.032 \\
\hline Cold carcass weight $(\mathrm{kg})$ & $15.26 \pm 2.31$ & $16.25 \pm 1.66$ & $15.88 \pm 1.83$ & $14.86 \pm 0.97$ & 0.541 & 0.938 & 0.094 \\
\hline Dressing (\%) & $42.99^{a} \pm 2.44$ & $44.95^{\mathrm{b}} \pm 1.08$ & $43.28^{a} \pm 3.23$ & $45.42^{b} \pm 2.49$ & 0.508 & 0.017 & 0.912 \\
\hline
\end{tabular}

$a, b$ Means in the same row per main effect bearing different letters differ $(P \leq 0.05)^{*}$

The choice of the particular six muscles studied; Longissimus thoracis et lumborum (LTL), Semimembranosus (SM), Biceps femoris (BF), Supraspinatus (SS), Infraspinatus (IS), and Semitendinosus (ST), was to obtain a set of muscles representing a variation in tenderness and other quality parameters due to their different anatomical positions, func- 
tions and commercial value. Means and standard errors of breed and sex on $\mathrm{pH}_{\mathrm{u}}, \mathrm{T}_{\mathrm{u}}$, muscle water holding capacity (WHC), percentage purge, Warner Bratzler shear force (WBSF), myofibril fragment length (MFL), intra muscular fat (IMF), collagen characteristics, and meat colour (CIE L*, $a^{*}, b^{*}$, Chroma and Hue-angle) for each of these six muscles are presented in Tables 2 to 7 , respectively.

Large frame IVG presented higher $\mathrm{pHu}$ values $(\mathrm{P} \leq 0.05)$ compared to that of $\mathrm{BG}$ for LTL, BF, and ST muscles, with SM and SS having a tendency $(\mathrm{P} \leq 0.10)$ to show breed differences. Sex differences for $\mathrm{pHu}$ were more prominent $(\mathrm{P} \leq 0.05)$ for $\mathrm{SM}$, SS, with $\mathrm{ST}$ showing both breed and sex differences and therefor a tendency $(P \leq 0.10)$ to have breed $x$ sex interactions. The IS muscle ( 6.1) showed on average the highest $\mathrm{pH}$, but no differences between breed and sex. In the muscles where $\mathrm{pH}_{\mathrm{u}}$ differences were found, the IVG seemed to have the higher $\mathrm{pH}$ compared to BG. When sex differences arose, the wethers always tended to have higher $\mathrm{pH}_{\mathrm{u}}$ than the bucks. On average, the SS measured a $\mathrm{pH}_{\mathrm{u}}$ of $\sim 5.9$, followed by BF and ST with $\mathrm{pH}$ u between 5.7 and 5.9.

Although there is some tendencies of breed and sex differences at 1 day post-mortem for some muscles, it is only after 4 days post-mortem that significant differences were observed in pressed out water (WHC). Water holding capacity mostly vary between 0.35 to 0.40 measured at 4 days post-mortem, but LTL measured 0.43 to 0.45 , respectively for BG and IVG wethers compared to 0.38 and 0.39 , respectively for BG and IVG bucks. Significant breed and sex effects for WHC at 4 days post-mortem were recorded for SM and SS muscles although the ratio was not as high as for the LTL. Only IS presented a breed difference for percentage purge with that of IVG $(0.62 \%-0.82 \%)$ significantly lower than that of BG $(0.97 \%-1.20 \%)$. It was observed that overall IS and BF seemed to have lower percentage purge than that of the other muscles ( $>1.5 \%$ ) (Results not shown).

Tenderness related sex effects were recorded for the BF (MFL 1 and 4 days post-mortem) and ST (WBSF 1 day post-mortem) muscles, while a tendency $(\mathrm{P} \leq 0.1)$ for an interaction between sex and breed was recorded for MFL at 1 day post-mortem for the SM muscles (Table 3). The BF wether muscle measured shorter MFL than that of the buck muscle (Table 4). Differences were found between the different muscles (results not shown). Some numerical tenderisation from 1 to 4 days post-mortem can be observed in each of the Tables 2 to 7, with SM, SS and IS being the most tender after 4 days post-mortem.

All the muscles showed a sex-effect $(\mathrm{P} \leq 0.05)$ for IMF (Tables 2 to 7$)$. Wether muscles overall recorded higher percentage IMF than that of bucks in LTL, SM, BF, SS, IS and ST. IVG bucks recorded the lowest values (1.1\%) in the IS muscles (Table 6) and BG wethers recorded the highest values of $4.18 \%$ in the BF muscle (Table 4 ). For most muscles, the bucks had about $1 \%$ less IMF than that of the wethers whilst the buck BF muscle had up to $2 \%$ less IMF than that of its equivalent wether muscle.

There were no significant effects of breed and sex on any of the collagen characteristics among the six muscles studied (Tables 2 to 7 ). However, there were tendencies ( $\mathrm{P} \leq$ 0.1) observed for IVG buck LTL and BG and IVG buck ST to have higher collagen solubility levels.

Meat colour differences related to the sex-effect were noted; $L^{*}$ (lightness) differences were observed in LTL (1 day post-mortem), SM (1 and 4 days post-mortem), BF (1 day post-mortem), SS (1 and 4 days post-mortem), and IS (1 day post-mortem), with a trend in the ST for a breed $x$ sex interaction. For these muscles wethers recorded lower $L^{*}$ values (darker meat) than the bucks. A sex effect for redness $\left(a^{*}\right)$ and Chroma (saturation index) were experienced in LTL (1 day post-mortem), SM (1 day post-mortem), BF (1 day post-mortem), and SS (1 day post-mortem). These muscles from wethers seem darker and brighter red than those of bucks especially at 1 day post-mortem. At 4 days post-mortem the Hue-angles (discoloration) of wether LTL, SM, SS and IS were lower than that of the corresponding buck muscles. Significant breed $x$ sex interactions were observed for the Chroma of the SM and ST and a trend in BF at 4 days post-mortem indicating towards a higher saturation index for BG wethers and IVG bucks. No breed or sex differences were detected for $b^{*}$ (yellowness) for any of the muscles. 
Table 2. Least square means and standard error of means for meat tenderness, meat colour and related physiological characteristics of buck and wether Boer Goat (BG) and Indigenous Veld Goats (IVG) of the Longissimus thoracis et lumborum (LTL) muscle

\begin{tabular}{|c|c|c|c|c|c|c|c|}
\hline \multicolumn{8}{|c|}{ Breed } \\
\hline & \multicolumn{2}{|l|}{ Boer Goat } & \multicolumn{2}{|c|}{ Indigenous Veld Goat } & \multicolumn{3}{|c|}{ Significance ( $p-$ Values $)$} \\
\hline & Bucks & Wethers & Bucks & Wethers & Breed & Sex & Breed \\
\hline & & & & & & & Sex \\
\hline $\mathrm{pH}_{\mathrm{u}}$ & $5.54^{\mathrm{a}} \pm 0.18$ & $5.60^{a} \pm 0.05$ & $5.67^{\mathrm{b}} \pm 0.11$ & $5.72^{\mathrm{b}} \pm 0.18$ & 0.011 & 0.241 & 0.944 \\
\hline \multicolumn{8}{|l|}{ Water holding capacity } \\
\hline 1 day $p m^{\sharp}$ & $0.41 \pm 0.03$ & $0.39 \pm 0.06$ & $0.38 \pm 0.04$ & $0.37 \pm 0.05$ & 0.101 & 0.384 & 0.642 \\
\hline 4 days $p m$ & $0.38^{a} \pm 0.04$ & $0.45^{\mathrm{b}} \pm 0.08$ & $0.39^{a} \pm 0.08$ & $0.43^{\mathrm{b}} \pm 0.07$ & 0.979 & 0.018 & 0.515 \\
\hline Purge $(\%)$ & $1.71 \pm 0.84$ & $1.86 \pm 0.78$ & $2.00 \pm 1.02$ & $1.96 \pm 0.79$ & 0.495 & 0.836 & 0.721 \\
\hline \multicolumn{8}{|l|}{ Warner Bratzler Shear force } \\
\hline 1 day $p m(\mathrm{~N})$ & $58.5 \pm 1.10$ & $59.0 \pm 1.17$ & $57.4 \pm 1.15$ & $59.5 \pm 1.05$ & 0.958 & 0.752 & 0.834 \\
\hline 4 days $p m(\mathrm{~N})$ & $46.5 \pm 1.14$ & $40.5 \pm 1.12$ & $43.3 \pm 0.88$ & $42.9 \pm 1.22$ & 0.842 & 0.395 & 0.499 \\
\hline \multicolumn{8}{|l|}{ Myofibril fragment length } \\
\hline 1 day $p m(\mu \mathrm{m})$ & $37.16 \pm 5.46$ & $35.55 \pm 4.83$ & $35.26 \pm 5.05$ & $37.42 \pm 5.04$ & 0.351 & 0.220 & 0.319 \\
\hline 4 days $p m(\mu \mathrm{m})$ & $33.62 \pm 6.21$ & $29.63 \pm 2.01$ & $30.32 \pm 5.07$ & $29.85 \pm 6.14$ & 0.471 & 0.332 & 0.426 \\
\hline \multicolumn{8}{|l|}{ Marbling* } \\
\hline IMF (\% Fat) & $1.97^{a} \pm 1.11$ & $2.58^{\mathrm{b}} \pm 1.35$ & $1.49^{a} \pm 0.94$ & $2.59^{b} \pm 0.70$ & 0.620 & 0.017 & 0.473 \\
\hline \multicolumn{8}{|l|}{ Collagen characteristics } \\
\hline Collagen solubility (\%) & $36.68 \pm 10.69$ & $37.55 \pm 11.25$ & $38.63 \pm 9.83$ & $35.49 \pm 11.13$ & 0.973 & 0.722 & 0.707 \\
\hline Soluble collagen $\left(\mathrm{mg} / \mathrm{g}^{\sharp}\right)$ & $1.37^{x} \pm 0.58$ & $1.40^{x} \pm 0.42$ & $1.66^{y} \pm 0.48$ & $1.27^{x} \pm 0.38$ & 0.958 & 0.501 & 0.080 \\
\hline Insoluble collagen (mg/g) & $2.40 \pm 0.54$ & $2.50 \pm 0.91$ & $2.71 \pm 0.42$ & $2.40 \pm 0.71$ & 0.549 & 0.232 & 0.229 \\
\hline Total collagen $(\mathrm{mg} / \mathrm{g})$ & $3.68 \pm 0.85$ & $3.80 \pm 0.85$ & $4.24 \pm 0.39$ & $3.59 \pm 0.78$ & 0.566 & 0.222 & 0.160 \\
\hline \multicolumn{8}{|l|}{ Meat colour characteristics } \\
\hline L D65 SCE 1 day $p m$ & $35.61^{\mathrm{a}} \pm 2.12$ & $33.50^{\mathrm{b}} \pm 1.20$ & $35.11^{\mathrm{a}} \pm 2.60$ & $33.20^{\mathrm{b}} \pm 2.47$ & 0.877 & 0.010 & 0.545 \\
\hline L D65 SCE 4 days $p m$ & $36.65 \pm 3.18$ & $34.75 \pm 2.67$ & $35.28 \pm 1.35$ & $34.84 \pm 2.79$ & 0.755 & 0.471 & 0.238 \\
\hline a*D65 SCE 1 day pm & $9.45^{\mathrm{a}} \pm 0.84$ & $11.25^{\mathrm{b}} \pm 0.76$ & $9.90^{\mathrm{a}} \pm 1.60$ & $10.53^{\mathrm{b}} \pm 1.27$ & 0.966 & 0.004 & 0.139 \\
\hline $\mathrm{a}^{*} \mathrm{D} 65$ SCE 4 days $p m$ & $9.75 \pm 1.25$ & $10.91 \pm 1.12$ & $10.09 \pm 0.96$ & $10.43 \pm 1.44$ & 0.736 & 0.168 & 0.208 \\
\hline $\mathrm{b}^{*}$ D65 SCE 1 day $p m$ & $11.16 \pm 1.41$ & $11.26 \pm 1.18$ & $11.10 \pm 1.81$ & $12.14 \pm 1.41$ & 0.371 & 0.236 & 0.354 \\
\hline $\mathrm{b}^{*}$ D65 SCE 4 days $p m$ & $13.04 \pm 0.94$ & $12.64 \pm 0.65$ & $12.52 \pm 0.85$ & $12.48 \pm 0.91$ & 0.209 & 0.413 & 0.499 \\
\hline Chroma D65 SCE 1 day pm & $14.66^{\mathrm{a}} \pm 1.30$ & $15.95^{\mathrm{b}} \pm 1.02$ & $14.93^{\mathrm{a}} \pm 1.96$ & $16.13^{\mathrm{b}} \pm 1.39$ & 0.486 & 0.015 & 0.898 \\
\hline 4 Chroma D65 SCE days pm & $16.34 \pm 1.13$ & $16.74 \pm 0.06$ & $16.11 \pm 1.10$ & $16.18 \pm 1.27$ & 0.340 & 0.577 & 0.680 \\
\hline Hue angle D65 SCE 1 day pm & $49.58^{x} \pm 4.02$ & $44.96^{\mathrm{y}} \pm 3.51$ & $48.76^{x} \pm 6.09$ & $47.74^{y} \pm 2.73$ & 0.388 & 0.059 & 0.139 \\
\hline Hue angle D65 SCE 4 days pm & $53.36^{\mathrm{a}} \pm 3.86$ & $49.36^{b} \pm 2.62$ & $51.16^{\mathrm{a}} \pm 2.39$ & $50.16^{b} \pm 3.49$ & 0.724 & 0.026 & 0.116 \\
\hline \multicolumn{8}{|c|}{$a, b$ Means in the same row per main effect bearing different letters differ $(P \leq 0.05)$} \\
\hline \multicolumn{8}{|c|}{$x, y$ Means in the same row per main effect bearing different letters was considered a tendency to differ $(P \leq 0.1)$} \\
\hline \multicolumn{8}{|l|}{$\# p m=$ post-mortem } \\
\hline
\end{tabular}


Table 3. Least square means and standard error of means for meat tenderness, meat colour and related physiological characteristics of buck and wether Boer Goat (BG) and Indigenous Veld Goats (IVG) of Semimembranosus (SM) muscle

\begin{tabular}{|c|c|c|c|c|c|c|c|}
\hline \multicolumn{8}{|c|}{ Breed } \\
\hline & \multicolumn{2}{|c|}{ Boer Goat } & \multicolumn{2}{|c|}{ Indigenous Veld Goat } & \multicolumn{3}{|c|}{ Significance ( $p$ - Values) } \\
\hline & Bucks & Wethers & Bucks & Wethers & Breed & Sex & Breed \\
\hline & & & & & & & Sex \\
\hline $\mathrm{pHu}_{\mathrm{u}}$ & $5.89^{a} \pm 0.27$ & $5.98^{\mathrm{ab}} \pm 0.11$ & $5.91^{\mathrm{a}} \pm 0.12$ & $6.17^{b} \pm 0.25$ & 0.092 & 0.017 & 0.267 \\
\hline \multicolumn{8}{|l|}{ Water holding capacity } \\
\hline 1 day $p m^{\#}$ & $0.35^{x} \pm 0.03$ & $0.35^{x} \pm 0.03$ & $0.35^{x} \pm 0.06$ & $0.31^{\mathrm{y}} \pm 0.04$ & 0.205 & 0.078 & 0.165 \\
\hline 4 days $p m$ & $0.35^{\mathrm{ab}} \pm 0.03$ & $0.35^{\mathrm{ab}} \pm 0.04$ & $0.36^{a} \pm 0.06$ & $0.41^{\mathrm{b}} \pm 0.03$ & 0.019 & 0.026 & 0.185 \\
\hline Purge (\%) & $1.89 \pm 0.48$ & $2.21 \pm 1.12$ & $1.60 \pm 1.03$ & $1.92 \pm 1.00$ & 0.384 & 0.306 & 0.999 \\
\hline \multicolumn{8}{|l|}{ Warner Bratzler Shear force } \\
\hline 1 day $p m(\mathrm{~N})$ & $37.6 \pm 0.44$ & $37.4 \pm 0.60$ & $39.7 \pm 0.50$ & $35.8 \pm 0.71$ & 0.908 & 0.415 & 0.230 \\
\hline 4 days $p m(\mathrm{~N})$ & $33.1 \pm 0.43$ & $31.9 \pm 0.84$ & $34.7 \pm 0.49$ & $30.0 \pm 0.69$ & 0.968 & 0.177 & 0.420 \\
\hline \multicolumn{8}{|l|}{ Myofibril fragment length } \\
\hline 1 day $p m(\mu \mathrm{m})$ & $41.06 \pm 5.85$ & $45.03 \pm 5.03$ & $44.08 \pm 4.74$ & $42.13 \pm 2.73$ & 0.883 & 0.560 & 0.066 \\
\hline 4 days $p m(\mu \mathrm{m})$ & $38.64 \pm 6.78$ & $37.85 \pm 5.78$ & $40.22 \pm 3.62$ & $35.46 \pm 4.60$ & 0.803 & 0.130 & 0.276 \\
\hline \multicolumn{8}{|l|}{ Marbling* } \\
\hline IMF ( $\%$ Fat) & $1.94^{\mathrm{a}} \pm 1.09$ & $3.05^{\mathrm{b}} \pm 1.53$ & $1.76^{\mathrm{a}} \pm 1.05$ & $2.76^{\mathrm{b}} \pm 0.80$ & 0.689 & 0.008 & 0.888 \\
\hline \multicolumn{8}{|l|}{ Collagen characteristics } \\
\hline Collagen solubility (\%) & $35.19 \pm 11.59$ & $27.58 \pm 9.62$ & $32.91 \pm 5.68$ & $33.03 \pm 12.27$ & 0.935 & 0.236 & 0.572 \\
\hline Soluble collagen $\left(\mathrm{mg} / \mathrm{g}^{\sharp}\right)$ & $2.55 \pm 1.30$ & $1.76 \pm 0.76$ & $2.09 \pm 0.53$ & $2.04 \pm 1.01$ & 0.602 & 0.624 & 0.388 \\
\hline Insoluble collagen (mg/g) & $4.43 \pm 0.45$ & $4.60 \pm 0.67$ & $4.39 \pm 0.56$ & $4.11 \pm 0.78$ & 0.647 & 0.207 & 0.384 \\
\hline Total collagen (mg/g) & $6.82 \pm 1.60$ & $6.21 \pm 1.03$ & $6.32 \pm 0.81$ & $5.99 \pm 0.97$ & 0.705 & 0.175 & 0.467 \\
\hline \multicolumn{8}{|l|}{ Meat colour characteristics } \\
\hline L D65 SCE 1 day $p m$ & $35.74^{\mathrm{a}} \pm 3.03$ & $33.78^{\mathrm{b}} \pm 1.84$ & $37.24^{\mathrm{a}} \pm 2.36$ & $33.01^{\mathrm{b}} \pm 1.47$ & 0.894 & 0.0003 & 0.199 \\
\hline L D65 SCE 4 days $p m$ & $36.94^{\mathrm{a}} \pm 3.22$ & $34.06^{b} \pm 2.99$ & $36.33^{\mathrm{a}} \pm 2.08$ & $34.14^{\mathrm{b}} \pm 2.72$ & 0.501 & 0.012 & 0.270 \\
\hline $\mathrm{a}^{*}$ 665 SCE 1 day $p m$ & $10.55^{\mathrm{a}} \pm 1.40$ & $12.36^{\mathrm{b}} \pm 1.66$ & $10.30^{\mathrm{a}} \pm 1.32$ & $11.74^{b} \pm 1.72$ & 0.388 & 0.003 & 0.060 \\
\hline $\mathrm{a}^{*}$ D65 SCE 4 days $p m$ & $9.85^{\mathrm{a}} \pm 2.03$ & $12.30^{\mathrm{b}} \pm 1.84$ & $11.17^{\mathrm{b}} \pm 1.63$ & $10.37^{\mathrm{a}} \pm 2.21$ & 0.066 & 0.111 & 0.018 \\
\hline $\mathrm{b}^{*}$ D65 SCE 1 day $p m$ & $11.91 \pm 1.31$ & $12.06 \pm 1.37$ & $12.31 \pm 0.67$ & $12.07 \pm 1.31$ & 0.318 & 0.474 & 0.580 \\
\hline $\mathrm{b}^{*}$ D65 SCE 4 days $p m$ & $12.71 \pm 1.21$ & $12.68 \pm 0.63$ & $13.26 \pm 0.67$ & $12.23 \pm 1.38$ & 0.828 & 0.353 & 0.512 \\
\hline Chroma D65 SCE 1 day pm & $15.99 \mathrm{a} \pm 1.49$ & $17.33^{\mathrm{b}} \pm 1.91$ & $16.12^{\mathrm{a}} \pm 0.90$ & $16.89^{\mathrm{b}} \pm 1.84$ & 0.754 & 0.018 & 0.375 \\
\hline Chroma D65 SCE 4 days pm & $16.14^{\mathrm{a}} \pm 2.06$ & $17.71^{\mathrm{b}} \pm 1.61$ & $17.41^{\mathrm{b}} \pm 1.43$ & $16.16^{\mathrm{a}} \pm 1.99$ & 0.078 & 0.185 & 0.024 \\
\hline Hue angle D65 SCE 1 day pm & $48.71^{\mathrm{a}} \pm 4.36$ & $44.49^{\mathrm{b}} \pm 3.34$ & $50.39 \mathrm{a} \pm 4.10$ & $44.9^{\mathrm{b}} \pm 2.28$ & 0.395 & 0.001 & 0.011 \\
\hline Hue angle D65 SCE 4 days $p m$ & $52.71^{\mathrm{a}} \pm 4.11$ & $46.21 \pm 3.61^{b}$ & $50.34^{\mathrm{a}} \pm 3.46$ & $48.29^{\mathrm{b}} \pm 4.23$ & 0.215 & 0.003 & 0.236 \\
\hline
\end{tabular}

$a, b$ Means in the same row per main effect bearing different letters differ $(P \leq 0.05)$

$x, y$ Means in the same row per main effect bearing different letters was considered a tendency to differ $(P \leq 0.1)$

\#pm = post-mortem

${ }^{*}$ Marbling = chemically determined intramuscular $\%$ fat (IMF); $L=$ lightness; $a^{*}=$ redness; $b^{*}=$ yellowness; Chroma = saturation index; Hue angle $=$ discolouration 
Table 4. Least square means and standard error of means for meat tenderness, meat colour and related physiological characteristics of buck and wether Boer Goat (BG) and Indigenous Veld Goats (IVG) of Biceps Femoris (BF) muscle

\begin{tabular}{|c|c|c|c|c|c|c|c|}
\hline \multicolumn{8}{|c|}{ Breed } \\
\hline & \multicolumn{2}{|c|}{ Boer Goat } & \multicolumn{2}{|c|}{ Indigenous Veld Goat } & \multicolumn{3}{|c|}{ Significance ( $p-$ Values) } \\
\hline & Bucks & Wethers & Bucks & Wethers & Breed & Sex & Breed \\
\hline & & & & & & & Sex \\
\hline $\mathrm{pHu}$ & $5.74^{\mathrm{a}} \pm 0.11$ & $5.71^{\mathrm{a}} \pm 0.14$ & $5.82^{\mathrm{b}} \pm 0.13$ & $5.91^{\mathrm{b}} \pm 0.16$ & 0.003 & 0.477 & 0.204 \\
\hline \multicolumn{8}{|l|}{ Water holding capacity } \\
\hline 1 day $p m^{\#}$ & $0.38^{\mathrm{y}} \pm 0.04$ & $0.38^{y} \pm 0.05$ & $0.36^{x} \pm 0.04$ & $0.35^{x} \pm 0.05$ & 0.096 & 0.550 & 0.686 \\
\hline 4 days $p m$ & $0.35 \pm 0.04$ & $0.41 \pm 0.06$ & $0.37 \pm 0.04$ & $0.37 \pm 0.06$ & 0.647 & 0.167 & 0.074 \\
\hline Purge (\%) & $0.96 \pm 0.34$ & $1.00 \pm 0.40$ & $0.97 \pm 0.27$ & $0.70 \pm 0.35$ & 0.182 & 0.282 & 0.188 \\
\hline \multicolumn{8}{|l|}{ Warner Bratzler Shear force } \\
\hline 1 day $p m(\mathrm{~N})$ & $55.8 \pm 1.06$ & $47.1 \pm 1.52$ & $49.9 \pm 1.09$ & $47.6 \pm 1.43$ & 0.444 & 0.211 & 0.455 \\
\hline 4 days $p m(\mathrm{~N})$ & $44.5 \pm 0.82$ & $34.4 \pm 0.78$ & $40.9 \pm 0.96$ & $42.1 \pm 1.36$ & 0.652 & 0.213 & 0.102 \\
\hline \multicolumn{8}{|l|}{ Myofibril fragment length } \\
\hline 1 day $p m(\mu \mathrm{m})$ & $43.57^{a} \pm 9.93$ & $35.01^{b} \pm 5.51$ & $40.81^{\mathrm{a}} \pm 6.80$ & $38.89^{b} \pm 6.50$ & 0.989 & 0.046 & 0.188 \\
\hline 4 days $p m(\mu \mathrm{m})$ & $35.11^{\mathrm{a}} \pm 5.76$ & $28.26^{\mathrm{b}} \pm 3.54$ & $33.29^{a} \pm 7.04$ & $32.21^{\mathrm{b}} \pm 5.27$ & 0.724 & 0.044 & 0.128 \\
\hline \multicolumn{8}{|l|}{ Marbling* } \\
\hline IMF (\% Fat) & $2.75^{\mathrm{a}} \pm 1.85$ & $4.18^{\mathrm{b}} \pm 2.46$ & $1.88^{\mathrm{a}} \pm 1.29$ & $3.74^{\mathrm{b}} \pm 0.74$ & 0.345 & 0.005 & 0.694 \\
\hline \multicolumn{8}{|l|}{ Collagen characteristics } \\
\hline Collagen solubility (\%) & $37.88 \pm 14.34$ & $34.50 \pm 7.73$ & $27.93 \pm 9.14$ & $37.33 \pm 16.13$ & 0.450 & 0.418 & 0.143 \\
\hline Soluble collagen $\left(\mathrm{mg} / \mathrm{g}^{\sharp}\right)$ & $2.80 \pm 1.67$ & $2.46 \pm 1.44$ & $1.82 \pm 0.78$ & $2.43 \pm 1.21$ & 0.218 & 0.286 & 0.646 \\
\hline Insoluble collagen (mg/g) & $4.27 \pm 0.97$ & $4.49 \pm 0.87$ & $4.67 \pm 0.43$ & $4.09 \pm 1.11$ & 0.519 & 0.505 & 0.974 \\
\hline Total collagen (mg/g) & $6.92 \pm 2.22$ & $6.81 \pm 2.19$ & $6.33 \pm 0.91$ & $6.36 \pm 1.25$ & 0.466 & 0.467 & 0.938 \\
\hline \multicolumn{8}{|l|}{ Meat colour characteristics } \\
\hline L D65 SCE 1 day pm & $37.60^{\mathrm{a}} \pm 3.05$ & $33.29^{b} \pm 2.18$ & $37.11^{\mathrm{a}} \pm 2.38$ & $34.06^{\mathrm{b}} \pm 1.50$ & 0.744 & $<.0001$ & 0.246 \\
\hline L D65 SCE 4 days $p m$ & $38.00 \pm 2.56$ & $35.83 \pm 1.76$ & $36.68 \pm 2.09$ & $36.24 \pm 2.93$ & 0.965 & 0.432 & 0.160 \\
\hline$a^{*}$ D65 SCE 1 day $p m$ & $9.95^{\mathrm{a}} \pm 1.16$ & $12.29^{\mathrm{b}} \pm 0.99$ & $10.33^{\mathrm{ab}} \pm 1.62$ & $10.64^{\mathrm{ab}} \pm 1.41$ & 0.267 & 0.006 & 0.027 \\
\hline $\mathrm{a}^{*}$ D65 SCE 4 days $p m$ & $8.76^{a} \pm 1.17$ & $10.84^{\mathrm{b}} \pm 1.36$ & $9.78^{\mathrm{ab}} \pm 1.33$ & $9.25^{\mathrm{ab}} \pm 1.19$ & 0.648 & 0.085 & 0.004 \\
\hline $\mathrm{b}^{*}$ D65 SCE 1 day $p m$ & $11.81 \pm 1.33$ & $11.98 \pm 1.10$ & $11.89 \pm 1.14$ & $12.02 \pm 1.52$ & 0.860 & 0.729 & 0.997 \\
\hline $\mathrm{b}^{*}$ D65 SCE 4 days $p m$ & $11.71 \pm 1.31$ & $12.19 \pm 1.15$ & $11.84 \pm 1.10$ & $11.99 \pm 1.23$ & 0.985 & 0.445 & 0.671 \\
\hline Chroma D65 SCE 1 day pm & $15.49^{\mathrm{x}} \pm 1.40$ & $17.16^{\mathrm{y}} \pm 1.24$ & $15.79^{x} \pm 1.57$ & $16.11^{\mathrm{y}} \pm 1.67$ & 0.574 & 0.056 & 0.179 \\
\hline Chroma D65 SCE 4 days pm & $14.66^{x} \pm 1.62$ & $16.39^{z} \pm 1.59$ & $15.38^{y} \pm 1.64$ & $15.23^{y} \pm 1.29$ & 0.809 & 0.143 & 0.072 \\
\hline Hue angle D65 SCE 1 day pm & $49.84^{\mathrm{a}} \pm 3.94$ & $44.25^{\mathrm{b}} \pm 2.98$ & $49.21^{\mathrm{a}} \pm 4.49$ & $47.54^{\mathrm{b}} \pm 2.43$ & 0.243 & 0.005 & 0.064 \\
\hline Hue angle D65 SCE 4 days $p m$ & $53.22^{b} \pm 2.66$ & $48.95^{\mathrm{a}} \pm 3.26$ & $50.56^{\mathrm{ab}} \pm 2.33$ & $51.84^{\mathrm{ab}} \pm 3.73$ & 0.723 & 0.398 & 0.010 \\
\hline
\end{tabular}

$a, b$ Means in the same row per main effect bearing different letters differ $(P \leq 0.05)$

$x, y$ Means in the same row per main effect bearing different letters was considered a tendency to differ $(P \leq 0.1)$

\#pm = post-mortem

${ }^{*}$ Marbling = chemically determined intramuscular $\%$ fat (IMF); $L=$ lightness; $a^{*}=$ redness; $b{ }^{*}=$ yellowness; Chroma = saturation index; Hue angle $=$ discolouration 
Table 5. Least square means and standard error of means for meat tenderness, meat colour and related physiological characteristics of buck and wether Boer Goat (BG) and Indigenous Veld Goats (IVG) of Supraspinatus (SS) muscle

\begin{tabular}{|c|c|c|c|c|c|c|c|}
\hline \multicolumn{8}{|c|}{ Breed } \\
\hline & \multicolumn{2}{|c|}{ Boer Goat } & \multicolumn{2}{|c|}{ Indigenous Veld Goat } & \multicolumn{3}{|c|}{ Significance ( $p-$ Values) } \\
\hline & Bucks & Wethers & Bucks & Wethers & Breed & Sex & Breed \\
\hline & & & & & & & Sex \\
\hline $\mathrm{pHu}$ & $5.89^{\mathrm{a}} \pm 0.27$ & $5.98^{\mathrm{b}} \pm 0.11$ & $5.91^{\mathrm{a}} \pm 0.12$ & $6.17^{b} \pm 0.25$ & 0.092 & 0.017 & 0.267 \\
\hline \multicolumn{8}{|l|}{ Water holding capacity } \\
\hline 1 day $p m^{\#}$ & $0.35^{x} \pm 0.03$ & $0.35^{x} \pm 0.03$ & $0.35^{x} \pm 0.06$ & $0.31^{y} \pm 0.04$ & 0.205 & 0.078 & 0.165 \\
\hline 4 days $p m$ & $0.35^{\mathrm{ab}} \pm 0.03$ & $0.35^{\mathrm{ab}} \pm 0.04$ & $0.36^{\mathrm{a}} \pm 0.06$ & $0.41^{\mathrm{b}} \pm 0.03$ & 0.019 & 0.026 & 0.185 \\
\hline Purge (\%) & $1.89 \pm 0.48$ & $2.21 \pm 1.12$ & $1.60 \pm 1.03$ & $1.92 \pm 1.00$ & 0.384 & 0.306 & 0.999 \\
\hline \multicolumn{8}{|l|}{ Warner Bratzler Shear force } \\
\hline 1 day $p m(\mathrm{~N})$ & $37.6 \pm 0.44$ & $37.4 \pm 0.60$ & $39.7 \pm 0.50$ & $35.8 \pm 0.71$ & 0.908 & 0.415 & 0.230 \\
\hline 4 days $p m(\mathrm{~N})$ & $33.1 \pm 0.43$ & $31.9 \pm 0.84$ & $34.7 \pm 0.49$ & $30.0 \pm 0.69$ & 0.968 & 0.177 & 0.420 \\
\hline \multicolumn{8}{|l|}{ Myofibril fragment length } \\
\hline 1 day $p m(\mu \mathrm{m})$ & $41.06 \pm 5.85$ & $45.03 \pm 5.03$ & $44.08 \pm 4.74$ & $42.13 \pm 2.73$ & 0.883 & 0.560 & 0.066 \\
\hline 4 days $p m(\mu \mathrm{m})$ & $38.64 \pm 6.78$ & $37.85 \pm 5.78$ & $40.22 \pm 3.62$ & $35.46 \pm 4.60$ & 0.803 & 0.130 & 0.276 \\
\hline \multicolumn{8}{|l|}{ Marbling* } \\
\hline IMF (\% Fat) & $1.94^{\mathrm{a}} \pm 1.09$ & $3.05^{\mathrm{b}} \pm 1.53$ & $1.76^{\mathrm{a}} \pm 1.05$ & $2.76^{\mathrm{b}} \pm 0.80$ & 0.689 & 0.008 & 0.888 \\
\hline \multicolumn{8}{|l|}{ Collagen characteristics } \\
\hline Collagen solubility (\%) & $35.19 \pm 11.59$ & $27.58 \pm 9.62$ & $32.91 \pm 5.68$ & $33.03 \pm 12.27$ & 0.741 & 0.297 & 0.202 \\
\hline Soluble collagen $\left(\mathrm{mg} / \mathrm{g}^{\sharp}\right)$ & $2.55 \pm 1.30$ & $1.76 \pm 0.76$ & $2.09 \pm 0.53$ & $2.04 \pm 1.01$ & 0.697 & 0.575 & 0.179 \\
\hline Insoluble collagen (mg/g) & $4.43 \pm 0.45$ & $4.60 \pm 0.67$ & $4.39 \pm 0.56$ & $4.11 \pm 0.78$ & 0.498 & 0.359 & 0.838 \\
\hline Total collagen (mg/g) & $6.82 \pm 1.60$ & $6.21 \pm 1.03$ & $6.32 \pm 0.81$ & $5.99 \pm 0.97$ & 0.987 & 0.946 & 0.128 \\
\hline \multicolumn{8}{|l|}{ Meat colour characteristics } \\
\hline L D65 SCE 1 day $p m$ & $35.74^{\mathrm{a}} \pm 3.03$ & $33.78^{b} \pm 1.84$ & $37.24^{\mathrm{a}} \pm 2.36$ & $33.01^{\mathrm{b}} \pm 1.47$ & 0.649 & 0.0003 & 0.222 \\
\hline L D65 SCE 4 days $p m$ & $36.94^{a} \pm 3.22$ & $34.06^{b} \pm 2.99$ & $36.33^{a} \pm 2.08$ & $34.14^{b} \pm 2.72$ & 0.991 & 0.012 & 0.450 \\
\hline a*D65 SCE 1 day pm & $10.55^{\mathrm{a}} \pm 1.40$ & $12.36^{\mathrm{b}} \pm 1.66$ & $10.30^{\mathrm{a}} \pm 1.32$ & $11.74^{\mathrm{b}} \pm 1.72$ & 0.558 & 0.003 & 0.720 \\
\hline a*D65 SCE 4 days $p m$ & $9.85^{\mathrm{a}} \pm 2.03$ & $12.30^{\mathrm{b}} \pm 1.84$ & $11.17^{\mathrm{ab}} \pm 1.63$ & $10.37^{\mathrm{ab}} \pm 2.21$ & 0.788 & 0.224 & 0.018 \\
\hline$b^{*}$ D65 SCE 1 day $p m$ & $11.91 \pm 1.31$ & $12.06 \pm 1.37$ & $12.31 \pm 0.67$ & $12.07 \pm 1.31$ & 0.623 & 0.885 & 0.597 \\
\hline $\mathrm{b}^{*}$ D65 SCE 4 days $p m$ & $12.71 \pm 1.21$ & $12.68 \pm 0.63$ & $13.26 \pm 0.67$ & $12.23 \pm 1.38$ & 0.853 & 0.131 & 0.153 \\
\hline Chroma D65 SCE 1 day pm & $15.99^{x} \pm 1.49$ & $17.33^{y} \pm 1.91$ & $16.12^{x} \pm 0.90$ & $16.89 \mathrm{y} \pm 1.84$ & 0.934 & 0.054 & 0.591 \\
\hline Chroma D65 SCE 4 days pm & $16.14^{\mathrm{a}} \pm 2.06$ & $17.71^{\mathrm{ab}} \pm 1.61$ & $17.41^{\mathrm{ab}} \pm 1.43$ & $16.16^{\mathrm{b}} \pm 1.99$ & 0.911 & 0.811 & 0.024 \\
\hline Hue angle D65 SCE 1 day pm & $48.71^{a} \pm 4.36$ & $44.49^{b} \pm 3.34$ & $50.39^{a} \pm 4.10$ & $44.9^{\mathrm{b}} \pm 2.28$ & 0.351 & 0.001 & 0.934 \\
\hline Hue angle D65 SCE 4 days pm & $52.71^{\mathrm{a}} \pm 4.11$ & $46.21^{b} \pm 3.61$ & $50.34^{a} \pm 3.46$ & $48.29^{b} \pm 4.23$ & 0.800 & 0.003 & 0.054 \\
\hline
\end{tabular}

$a, b$ Means in the same row per main effect bearing different letters differ $(P \leq 0.05)$

$x, y$ Means in the same row per main effect bearing different letters was considered a tendency to differ $(P \leq 0.1)$

\#pm = post-mortem

${ }^{*}$ Marbling = chemically determined intramuscular\% fat (IMF); $L=$ lightness; $a^{*}=$ redness; $b *$ yellowness; Chroma = saturation index; Hue angle= discolouration 
Table 6. Least square means and standard error of means for meat tenderness, meat colour and related physiological characteristics of buck and wether Boer Goat (BG) and Indigenous Veld Goats (IVG) of Infraspinatus (IS) muscle

\begin{tabular}{|c|c|c|c|c|c|c|c|}
\hline \multicolumn{8}{|c|}{ Breed } \\
\hline & \multicolumn{2}{|c|}{ Boer Goat } & \multicolumn{2}{|c|}{ Indigenous Veld Goat } & \multicolumn{3}{|c|}{ Significance ( $p$ - Values) } \\
\hline & Bucks & Wethers & Bucks & Wethers & Breed & Sex & Breed \\
\hline & & & & & & & Sex \\
\hline $\mathrm{pHu}$ & $5.97 \pm 0.26$ & $6.11 \pm 0.10$ & $6.09 \pm 0.24$ & $6.12 \pm 0.21$ & 0.324 & 0.247 & 0.446 \\
\hline \multicolumn{8}{|l|}{ Water holding capacity } \\
\hline 1 day $p m^{\#}$ & $0.36 \pm 0.05$ & $0.38 \pm 0.07$ & $0.34 \pm 0.05$ & $0.34 \pm 0.05$ & 0.195 & 0.791 & 0.606 \\
\hline 4 days $p m$ & $0.35 \pm 0.05$ & $0.39 \pm 0.06$ & $0.38 \pm 0.04$ & $0.37 \pm 0.05$ & 0.686 & 0.419 & 0.199 \\
\hline Purge (\%) & $0.97^{a} \pm 0.35$ & $1.20^{\mathrm{a}} \pm 0.57$ & $0.82^{\mathrm{b}} \pm 0.49$ & $0.62^{\mathrm{b}} \pm 0.23$ & 0.015 & 0.960 & 0.129 \\
\hline \multicolumn{8}{|l|}{ Warner Bratzler Shear force } \\
\hline 1 day $p m(\mathrm{~N})$ & $33.8 \pm 0.63$ & $31.9 \pm 0.45$ & $29.9 \pm 0.40$ & $30.0 \pm 0.68$ & 0.155 & 0.641 & 0.588 \\
\hline 4 days $p m(\mathrm{~N})$ & $26.9^{x} \pm 0.37$ & $28.9^{\mathrm{x}} \pm 0.42$ & $25.7 y \pm 0.39$ & $24.8^{\mathrm{y}} \pm 0.54$ & 0.083 & 0.726 & 0.331 \\
\hline \multicolumn{8}{|l|}{ Myofibril fragment length } \\
\hline 1 day $p m(\mu \mathrm{m})$ & $46.53 \pm 6.51$ & $42.70 \pm 4.59$ & $44.63 \pm 5.51$ & $44.43 \pm 8.29$ & 0.886 & 0.367 & 0.403 \\
\hline 4 days $p m(\mu \mathrm{m})$ & $41 . .41 \pm 7.32$ & $39.36 \pm 6.25$ & $38.78 \pm 4.06$ & $37.46 \pm 5.89$ & 0.232 & 0.407 & 0.856 \\
\hline \multicolumn{8}{|l|}{ Marbling* } \\
\hline IMF (\% Fat) & $1.49^{a} \pm 0.59$ & $2.70^{\mathrm{b}} \pm 1.10$ & $1.10^{a} \pm 0.66$ & $2.09^{\mathrm{b}} \pm 0.41$ & 0.092 & $<.0001$ & 0.641 \\
\hline \multicolumn{8}{|l|}{ Collagen characteristics } \\
\hline Collagen solubility (\%) & $37.05 \pm 10.26$ & $39.39 \pm 9.81$ & $38.31 \pm 11.58$ & $34.79 \pm 9.69$ & 0.513 & 0.873 & 0.538 \\
\hline Soluble collagen $\left(\mathrm{mg} / \mathrm{g}^{\sharp}\right)$ & $2.83 \pm 1.14$ & $2.76 \pm 1.22$ & $2.89 \pm 1.11$ & $2.33 \pm 0.74$ & 0.793 & 0.396 & 0.200 \\
\hline Insoluble collagen (mg/g) & $4.89 \pm 1.06$ & $4.18 \pm 1.15$ & $4.67 \pm 0.81$ & $4.47 \pm 0.81$ & 0.848 & 0.133 & 0.733 \\
\hline Total collagen (mg/g) & $7.55 \pm 1.55$ & $6.79 \pm 2.04$ & $7.39 \pm 1.21$ & $6.61 \pm 0.89$ & 0.891 & 0.131 & 0.598 \\
\hline \multicolumn{8}{|l|}{ Meat colour characteristics } \\
\hline L D65 SCE 1 day pm & $36.96^{\mathrm{a}} \pm 3.39$ & $34.64^{b} \pm 2.57$ & $38.36^{\mathrm{a}} \pm 2.32$ & $37.0^{\mathrm{b}} \pm 2.15$ & 0.057 & 0.048 & 0.537 \\
\hline L D65 SCE 4 days $p m$ & $37.61 \pm 3.34$ & $36.03 \pm 2.64$ & $38.21 \pm 2.43$ & $37.19 \pm 3.88$ & 0.461 & 0.221 & 0.785 \\
\hline a*D65 SCE 1 day pm & $8.22^{\mathrm{a}} \pm 1.92$ & $10.28^{b} \pm 1.45$ & $8.43^{\mathrm{a}} \pm 1.64$ & $9.03^{b} \pm 2.18$ & 0.519 & 0.040 & 0.244 \\
\hline a*D65 SCE 4 days pm & $8.86^{\mathrm{a}} \pm 1.70$ & $10.84^{b} \pm 2.08$ & $8.69^{\mathrm{a}} \pm 1.74$ & $9.60^{\mathrm{b}} \pm 2.42$ & 0.402 & 0.039 & 0.447 \\
\hline $\mathrm{b}^{*}$ D65 SCE 1 day pm & $10.60^{\mathrm{a}} \pm 1.52$ & $10.89^{\mathrm{a}} \pm 1.47$ & $12.13^{b} \pm 0.71$ & $11.17^{\mathrm{b}} \pm 0.97$ & 0.042 & 0.815 & 0.411 \\
\hline $\mathrm{b}^{*}$ D65 SCE 4 days $p m$ & $12.41 \pm 1.28$ & $12.20 \pm 1.34$ & $12.46 \pm 1.22$ & $11.98 \pm 1.02$ & 0.831 & 0.364 & 0.712 \\
\hline Chroma D65 SCE 1 day pm & $13.52 \pm 2.18$ & $15.03 \pm 1.98$ & $14.53 \pm 1.98$ & $14.48 \pm 1.84$ & 0.642 & 0.289 & 0.254 \\
\hline Chroma D65 SCE 4 days pm & $15.36 \pm 1.67$ & $16.36 \pm 2.20$ & $15.32 \pm 1.72$ & $15.54 \pm 1.86$ & 0.545 & 0.332 & 0.508 \\
\hline Hue angle D65 SCE 1 day pm & $52.73^{\mathrm{a}} \pm 4.83$ & $47.01^{\mathrm{b}} \pm 2.23$ & $55.90^{\mathrm{a}} \pm 4.28$ & $50.57^{b} \pm 4.40$ & 0.034 & 0.001 & 0.586 \\
\hline Hue angle D65 SCE 4 days pm & $54.86 \pm 5.07$ & $49.16 \pm 4.10$ & $55.66 \pm 4.87$ & $52.18 \pm 7.07$ & 0.409 & 0.017 & 0.544 \\
\hline
\end{tabular}

$a, b$ Means in the same row per main effect bearing different letters differ $(P \leq 0.05)$

$x, y$ Means in the same row per main effect bearing different letters was considered a tendency to differ $(P \leq 0.1)$

\#pm = post-mortem

${ }^{*}$ Marbling = chemically determined intramuscular $\%$ fat (IMF); L = lightness; $a^{*}=$ redness; $b^{*}=$ yellowness; Chroma = saturation index; Hue angle $=$ discolouration 
Table 7. Least square means and standard error of means for meat tenderness, meat colour and related physiological characteristics of buck and wether Boer Goat (BG) and Indigenous Veld Goats (IVG) of Semitendinosus (ST) muscle

\begin{tabular}{|c|c|c|c|c|c|c|c|}
\hline \multicolumn{8}{|c|}{ Breed } \\
\hline & \multicolumn{2}{|c|}{ Boer Goat } & \multicolumn{2}{|c|}{ Indigenous Veld Goat } & \multicolumn{3}{|c|}{ Significance ( $p$ - Values) } \\
\hline & Bucks & Wethers & Bucks & Wethers & Breed & Sex & Breed \\
\hline & & & & & & & Sex \\
\hline $\mathrm{pHu}$ & $5.66^{\mathrm{a}} \pm 0.11$ & $5.69^{a} \pm 0.06$ & $5.71^{\mathrm{b}} \pm 0.13$ & $5.89^{b} \pm 0.18$ & 0.004 & 0.021 & 0.091 \\
\hline \multicolumn{8}{|l|}{ Water holding capacity } \\
\hline 1 day $p m^{\#}$ & $0.37 \pm 0.04$ & $0.35 \pm 0.05$ & $0.38 \pm 0.03$ & $0.37 \pm 0.04$ & 0.432 & 0.394 & 0.705 \\
\hline 4 days $p m$ & $0.38 \pm 0.07$ & $0.39 \pm 0.06$ & $0.39 \pm 0.04$ & $0.41 \pm 0.05$ & 0.265 & 0.421 & 0.750 \\
\hline Purge (\%) & $1.49 \pm 0.97$ & $1.62 \pm 0.83$ & $1.93 \pm 1.53$ & $1.54 \pm 0.92$ & 0.624 & 0.708 & 0.479 \\
\hline \multicolumn{8}{|l|}{ Warner Bratzler Shear force } \\
\hline 1 day $p m(\mathrm{~N})$ & $50.8^{\mathrm{a}} \pm 0.51$ & $44.8^{\mathrm{b}} \pm 0.48$ & $44.8^{\mathrm{b}} \pm 0.48$ & $44.1^{\mathrm{b}} \pm 1.19$ & 0.440 & 0.047 & 0.736 \\
\hline 4 days $p m(\mathrm{~N})$ & $47.3 \pm 0.61$ & $41.4 \pm 0.32$ & $43.0 \pm 0.64$ & $40.8 \pm 1.23$ & 0.288 & 0.137 & 0.483 \\
\hline \multicolumn{8}{|l|}{ Myofibril fragment length } \\
\hline 1 day $p m(\mu \mathrm{m})$ & $46.48 \pm 4.56$ & $45.63 \pm 3.40$ & $44.06 \pm 5.03$ & $46.66 \pm 5.38$ & 0.662 & 0.553 & 0.274 \\
\hline 4 days $p m(\mu \mathrm{m})$ & $40.58 \pm 5.24$ & $38.44 \pm 4.41$ & $40.12 \pm 6.19$ & $38.51 \pm 8.17$ & 0.864 & 0.371 & 0.899 \\
\hline \multicolumn{8}{|l|}{ Marbling* } \\
\hline IMF (\% Fat) & $2.12^{\mathrm{a}} \pm 1.53$ & $2.76^{\mathrm{b}} \pm 1.50$ & $1.84^{\mathrm{a}} \pm 1.07$ & $2.93^{b} \pm 0.68$ & 0.980 & 0.040 & 0.590 \\
\hline \multicolumn{8}{|l|}{ Collagen characteristics } \\
\hline Collagen solubility (\%) & $37.09 \pm 11.22$ & $33.60 \pm 9.82$ & $35.31 \pm 7.75$ & $32.94 \pm 8.66$ & 0.821 & 0.404 & 0.690 \\
\hline Soluble collagen $\left(\mathrm{mg} / \mathrm{g}^{\sharp}\right)$ & $1.85^{x} \pm 0.52$ & $1.41^{y} \pm 0.47$ & $1.74^{x} \pm 0.75$ & $1.57 \mathrm{y} \pm 0.55$ & 0.058 & 0.059 & 0.757 \\
\hline Insoluble collagen (mg/g) & $3.36 \pm 1.07$ & $2.89 \pm 0.52$ & $3.10 \pm 0.30$ & $3.21 \pm 0.47$ & 0.688 & 0.128 & 0.136 \\
\hline Total collagen (mg/g) & $5.08 \pm 1.05$ & $4.20 \pm 0.57$ & $4.72 \pm 0.10$ & $4.70 \pm 0.71$ & 0.823 & 0.104 & 0.160 \\
\hline \multicolumn{8}{|l|}{ Meat colour characteristics } \\
\hline L D65 SCE 1 day $p m$ & $40.11^{x} \pm 2.05$ & $38.73^{y} \pm 1.68$ & $39.36^{y} \pm 0.98$ & $39.46^{y} \pm 2.62$ & 0.963 & 0.882 & 0.090 \\
\hline L D65 SCE 4 days $p m$ & $39.89 \pm 2.21$ & $39.58 \pm 2.99$ & $39.52 \pm 1.68$ & $38.28 \pm 3.03$ & 0.781 & 0.849 & 0.899 \\
\hline a*D65 SCE 1 day $p m$ & $7.58^{\mathrm{b}} \pm 1.22$ & $9.25^{\mathrm{b}} \pm 0.94$ & $8.17^{b} \pm 0.85$ & $7.63^{\mathrm{a}} \pm 1.27$ & 0.342 & 0.891 & 0.005 \\
\hline a*D65 SCE 4 days pm & $7.21^{\mathrm{a}} \pm 1.28$ & $8.50^{\mathrm{b}} \pm 1.63$ & $8.09^{\mathrm{a}} \pm 1.06$ & $8.96^{\mathrm{b}} \pm 1.61$ & 0.347 & 0.029 & 0.392 \\
\hline $\mathrm{b}^{*}$ D65 SCE 1 day $p m$ & $12.40 \pm 0.78$ & $12.79 \pm 1.09$ & $12.84 \pm 0.89$ & $12.76 \pm 0.73$ & 0.428 & 0.618 & 0.408 \\
\hline $\mathrm{b}^{*}$ D65 SCE 4 days $p m$ & $12.47 \pm 0.91$ & $12.73 \pm 0.93$ & $12.80 \pm 1.23$ & $13.23 \pm 0.80$ & 0.178 & 0.285 & 0.785 \\
\hline Chroma D65 SCE 1 day pm & $14.64^{\mathrm{a}} \pm 0.93$ & $15.89^{\mathrm{b}} \pm 1.11$ & $15.60^{\mathrm{b}} \pm 0.82$ & $14.79^{\mathrm{a}} \pm 1.08$ & 0.959 & 0.594 & 0.004 \\
\hline Chroma D65 SCE 4 days pm & $14.47^{x} \pm 1.23$ & $15.41^{\mathrm{y}} \pm 1.33$ & $15.19^{x} \pm 1.49$ & $15.86^{\mathrm{y}} \pm 0.90$ & 0.110 & 0.059 & 0.744 \\
\hline Hue angle D65 SCE 1 day pm & $59.04^{\mathrm{ab}} \pm 4.34$ & $54.45^{\mathrm{a}} \pm 3.42$ & $58.40^{\mathrm{ab}} \pm 3.14$ & $59.51^{\mathrm{b}} \pm 3.76$ & 0.236 & 0.936 & 0.029 \\
\hline Hue angle D65 SCE 4 days pm & $60.12 \pm 4.16$ & $56.94 \pm 5.15$ & $58.16 \pm 2.41$ & $55.96 \pm 5.36$ & 0.671 & 0.335 & 0.421 \\
\hline
\end{tabular}

$a, b$ Means in the same row per main effect bearing different letters differ $(P \leq 0.05)$

$x, y$ Means in the same row per main effect bearing different letters was considered a tendency to differ $(P \leq 0.1)$

"pm = post-mortem

${ }^{*}$ Marbling = chemically determined intramuscular\% fat (IMF); L = lightness; $a^{*}=$ redness; $b^{*}=$ yellowness; Chroma = saturation index; Hue angle $=$ discolouration 


\section{Discussion}

Compared to extensive studies on the influence of muscle source on meat quality indicators such as $\mathrm{pH}_{\mathrm{u}}$, chemical composition, tenderness, juiciness and colour attributes in other livestock, only limited studies examined these phenomena in chevon (goat) meat; with the focus mainly being on the LTL and SM muscles $[8,37,38]$. The present study investigated the meat quality of six different muscles (i.e. Longissimus thoracis et lumborum (LTL), Semimembranosus (SM), Biceps femoris (BF), Supraspinatus (SS), Infraspinatus (IS), and Semitendinosus (ST). The different muscles will not show the same values for $\mathrm{pHu}, \mathrm{WHC}$, percentage purge, WBSF, MFL, IMF, collagen characteristics and meat colour measurements, due to their different intrinsic characteristics [39].

Slightly higher $\mathrm{pH}_{\mathrm{u}}$ values for LTL and SM were reported by [8] and [40] compared to the present study (LTL and SM muscles showed similar but lower $\mathrm{pHu}$ values from 5.5 to 5.7). On average $\mathrm{pHu}_{\mathrm{u}}$ of 5.7 to 5.8 are reported [8] for both the LTL and SM with no differences between breeds and treatments, the latter included 30 seconds electrical stimulation (ES) under similar conditions and step wise chilling for non-stimulated (NS) carcasses. A pHu higher than 5.8 for LTL in goat carcasses were reported by [41, 42, 43], who all concluded that DFD was the cause of this higher $\mathrm{pHu}$. Interpretation of the results from the present study should consider that all the carcasses were electrically stimulated as a prevention of cold shortening, thereby causing the lower $\mathrm{pHu}$. Energy supplementation of the animals with commercial "Ram, lamb and ewe - 13" pellets during growth and limited pre-slaughter stress due to short transport distance from the grower facility to abattoir, combined with a short lairage period, probably contributed to a higher muscle glycogen and generally lower $\mathrm{pHu}$ values in certain muscles such as the LTL and SM.

In agreement with results of the current study, a faster rate of deposition for carcass and non-carcass fat and total fat for Jebel Akhdar Omani does and wethers raised under intensive management as compared to bucks have been reported [42, 43]. The present study's \% IMF composition ranges are higher than that reported for non-specified indigenous goats [5]. This could probably be due to differences between breed, age, nutritional plane, and sample size (number of animals). Goats tend to deposit most of their fat in the visceral rather than carcass depot and produce leaner carcasses [46] whilst the "indigenous" goat groups usually give inferior results compared to that of Boer Goat $[8$, 9, 10].

Notable relative high percentage IMF were measured in all the wether muscles compared to those of buck in both IVG and BG. However, this did not seem to have any effect on tenderness. It is speculated that the IMF value of $>4 \%$ in the BF muscle of the BG wethers combined with higher levels of ageing (low MFL values) may have contributed to a numerically lower WBSF; a difference of $10 \mathrm{~N}$. Despite variation in IMF\% levels between sex groups in other muscles, including the $\mathrm{BF}$, the mean IMF value across all muscles was probably too low to show any effect on tenderness. The intramuscular fat is not usually associated with shear force tenderness and [47] could find no effect of $\%$ IMF and WBSF for beef with IMF values between $6.8 \%$ and $20.9 \%$. Only when $\%$ IMF levels reached $33.9 \%$, the effect become significant. An early study [48], showed significant but low correlations with WBSF, which corresponds with the trends in our study. For sensory scores, the effect of \% IMF on tenderness experience becomes relevant as a result of the added effect of mouthfeel that is released during chewing. According to [49] marbling levels varying between $1.96 \%$ and $3.8 \%$ had no effect on consumers scores for beef tenderness (not Warner Bratzler shear force), but scores increased significantly at $5.6 \%$ and higher.

Although differences between the different muscles for all connective tissue characteristics were observed (statistical data not shown), which agrees with the findings of [29] for cattle, the differences in tenderness between sex could not be explained by conventional reasons such as differences in connective tissue properties and ageing. On average, the LTL muscles had the most advantageous post-mortem proteolytic activity (as 
indicated by the myofibril fragment length) and lowest total collagen, and despite the fact that ES was applied during slaughter, The LTL was still tough as indicated by the high WBSF. A possible explanation for the tougher LTL muscles could be the cooking method; the recommended cooking method for LTL is a dry cooking method [50], whilst in this investigation, the LTL and the rest of the muscles were cooked by means of a moisture cooking method (recommended for higher connective tissue cuts for mutton and beef [51]). Chevon LTL might have different physiological characteristics compared to the muscles of other domestic species that requires different cooking methods. This aspect warrants further research to help with the commercialising process and refining post-slaughter procedures that will benefit consumer perceptions of chevon.

The differences in muscle physiology between species could also explain some of the colour differences noted. Reported by [52], muscle-specificity in fresh meat from a medium sized wild ungulate, the blesbok (Damaliscus pygargus phillipsi) and observed that the blesbok Infraspinatus muscle was more colour-stable than the LTL and BF. This observation is different from that previously reported for fresh beef and suggests that game species have a unique biology and that the influence of muscle source on colour stability is species dependent [53]. These observations may support the idea that goat is a unique species, and that chevon should be approached differently from that of the other better known red meats such as beef and mutton. In general, the rate and extent of post-mortem glycolysis and ultimate $\mathrm{pH}$ of the muscle are critical factors that determine goat meat quality but more particular WHC and meat colour [53]. Contrary to [54], no breed differences in meat colour characteristics for the various BG and IVG muscles was experienced in this study. For the SM and SS muscles, wethers recorded higher $\mathrm{pH}_{\mathrm{u}}$ values, which also coincided with slightly darker muscles, i.e. lower $\mathrm{L}^{*}$ values and higher values for redness $\left(a^{*}\right)$ and consequently Chroma. Incidentally, there was no differences in purge between breed nor sex; this was to be expected as the animals had ad lib access to feed and were all treated the same ante mortem. This might have been due to the high $\mathrm{pH}_{\mathrm{u}}$ in general as all values were above 5.8 suggesting higher stress susceptibility in these specific animals [55].

Meat from intact male animals (bulls and rams) are generally darker compared to females and castrated males [56]. This is in contrast to the present study, where the wethers had darker meat $\left(L^{*}<35.0\right)$ compared to bucks $\left(L^{*}>36.9\right)$. Small and sometimes significant differences were found for other colour parameters where muscles of wethers in most cases tend to show more vivid colours (higher Chroma) and lower discolouration (lower Hue angle values). It is known that energy status immediately after slaughter has an influence on meat colour (lightness) and tenderness [57, 58].

\section{Conclusions}

Knowledge about meat quality of specific indigenous eco-types is limited as studies usually compare nonspecific "indigenous" goats with Boer Goat (well described). This study alleviates some misconceptions that exist about the potential quality of "indigenous" goat meat. More muscle meat quality differences were found between bucks and wethers than between Boer Goats and large frame Indigenous Veld Goats consisting of a mixture of the different goat eco-types. This study showed that the muscles of IVG large frame goats differed minimally from the same muscles derived from BG when finished off in the same feedlot. This study further showed that goat muscles have different characteristics than that of other red meat animals and warrant further research to understand this species' meat quality characteristics and the factor that influence it, better. More studies should also focus on understanding how to adapt/manage pre- and post-slaughter procedures to produce the best goat meat (chevon) eating experience.

Author Contributions: L.F., P.E.S. and L.C.H. were responsible for Conceptualization. G.L.v.W. was responsible for methodology, formal analysis, investigation and writing the original draft preparation. L.F., L.C.H. and P.E.S. were responsible for reviewing and editing. L.F. was responsi- 
ble for resources, supervision, project administration and funding acquisition. All authors have read and agreed to the published version of the manuscript.

Funding: This work was supported by the Red Meat Research and Development of South Africa (RMRDSA) and Technology and Human Resources for Industry Programme (THRIP) of the Department of Trade and Industry, Pretoria, South Africa, Grant number TP14080787990. The authors thank the Agricultural Research Council (ARC) for facilities and human resources.

Acknowledgments: The authors acknowledge the support given by the personnel of the ARC-Animal Production, Small Stock, Abattoir and Meat Technology sections for technical support.

Conflicts of Interest: The authors declare no conflicts of interest.

\section{References}

1. Indigenous goat breeds of South Africa. https://southafrica.co.za/indigenous-goat-breeds-of-south-africa.html (accessed 21 October 2021).

2. Van Wyk, G.L.; Hoffman, L.C.; Strydom, P.E.; Frylinck, L. Effect of Breed Types and Castration on Carcass Characteristics of Boer and Large Frame Indigenous Veld Goats of Southern Africa. Animals, 2020, 10, 1884. https://doi.org/10.3390/ani10101884.

3. Visser, C. A review on goats in southern Africa: An untapped genetic resource. Small Ruminant Research, 2019, 176, 11-16. https://doi.org/10.1016/j.smallrumres.2019.05.009.

4. Food and Agriculture Organization of the United Nations, Statistics Division (FAOSTAT). https://www.fao.org (accessed, 28 December 2020).

5. Tshabalala, P. A.; Strydom, P. E.; Webb, E. C.; de Kock, H. L. Meat quality of designated South African indigenous goat and sheep breeds. Meat Science, 2003, 65, 563 - 570. https://doi.org/10.1016/s0309-1740(02)00249-8.

6. Simela, L. Meat characteristics and the acceptability of chevon from South African indigenous goats. PhD Thesis, University of Pretoria, South Africa, 2005. http://hdl.handle.net/2263/29932.

7. Webb, E.C.; Casey, N.H.; Simela, L. Goat meat quality. Small Ruminant Research, 2005, 60, 153 - 166. https://doi.org/10.1016/j.smallrumres.2005.06.009.

8. Pophiwa, P.; Webb, E.C.; Frylinck, L. Meat quality characteristics of two South African goat breeds after applying electrical stimulation or delayed chilling of carcasses. Meat Science, 2016, 145, 107 - 114. http://dx.doi.org/10.4314/sajas.v47i6.7.

9. Pophiwa, P.; Webb, E.C.; Frylinck, L. "Carcass and meat quality of Boer and indigenous goats of South Africa under delayed chilling conditions." South African Journal of Animal Science, 2017, 47, 794 - 603. http://dx.doi.org/10.4314/sajas.v47i6.7.

10. Pophiwa, P.; Webb, E.C.; Frylinck, L. A review of factors affecting goat meat quality and mitigating strategies. Small Ruminant Research, 2020, 183, 106035. https://doi.org/10.1016/j.smallrumres.2019.106035.

11. Sacks, M.S.; Kronick, P.L.; Buechler, P.R. Contribution of intramuscular connective tissue to the viscoelastic properties of post-rigor bovine muscle. Journal of Food Science, 1988, 53, $19-24$.

12. Listrat, A.; Lebret, B.; Louveau, I.; Astruc, T.; Bonnet, M.; Lefaucheur, L.; Picard, B.; Bugeon, J. How Muscle Structure and Composition Influence Meat and Flesh Quality. The Scientific World Journal, 2016, 3182746. https://doi/10.1155/2016/3182746.

13. Font-i-Furnols, M.; Guerrero, L. Consumer preference, behaviour and perception about meat and meat products: An overview. Meat Science, 2014, 98, 361 - 371. https://doi.org/10.1016/j.meatsci.2014.06.025.

14. Sheridan, R.; Hoffman, L.C.; Ferreira, A.V. Meat quality of Boer Goat kids and Mutton merino lambs. 1. Commercial yields and chemical composition. Animal Science, 2003, 76, 63 - 71. https://doi.org/10.1017/S1357729800053327.

15. Schönfeldt H.C., Naude R.T., Bok W.; van Heerden S.M.; Smit R.; Boshoff E. Flavour and tenderness related quality characteristics of goat and sheep meat. Meat Science, 1993, 34, 363-379.

16. Schönfeldt H.C.; Naude R.T.; Bok W.; van Heerden S.M.; Swoden L.; Boshoff E Cooking and juiciness related quality characteristics of goat and sheep meat. Meat Science, 1993, 34, $381-394$.

17. Schönfeldt, H.C.; Strydom, P.E. Effect of age and cut on tenderness of South African beef. Meat Science, 2011, 87, 206 - 208. https://doi.org/10.1016/j. Meat Science 2010.10.011.

18. Strydom, P.E.; Frylinck, L.; Smith, M.F. Should electrical stimulation be applied when cold shortening is not a risk? Meat Science, 2005, 70, 733 - 742. https://doi.org/10.1016/j.meatsci.2005.03.010.

19. Irie, M.; Izumo, A.; Mohri, S. Rapid method for determining water-holding capacity in meat using video image analysis and simple formulae. Meat Science, 1996, 42, 95 - 102. https://doi.org/10.1016/0309-1740(95)00009-7.

20. American Meat Science Association (AMSA). Research Guidelines for Cookery and Evaluation, Second edition, Version, 1.02, 2016. Champaign, Illinois, USA. http://www.meatscience.org/sensory.

21. Honikel, J.L. Reference methods for the assessment of physical characteristics of meat. Meat Science, 1998, 49,447 - 457. https://doi.org/10.1016/s0309-1740(98)00034-5.

22. Culler, R.D.; Parrish, J.R.; Smith, G.C.; Cross, H.R. Relationship of myofibril fragmentation index to certain chemical, physical and sensory characteristics of bovine Longissimus muscle. Journal of Food Science, 1978; 43, 1177 - 1180. https://doi.org/10.1111/j.1365-2621.1978.tb15263.x.

23. Heinze, P.H.; Bruggemann, D. Ageing of beef: Influence of two ageing methods on sensory properties and myofibrillar proteins. Sciences des Aliments, 1994, 14, 387 - 399. 
24. Association of Official's Analytical Chemist (AOAC). Official Methods of Analyses (15th Edition), Washington, D.C. 1990.

25. Foster, M.L.; Gonzales, S.E. Soxtec Fat Analyzer for Determination of Total Fat in Meat: Collaborative Study. Journal of AOAC INTERNATIONAL, 1992, 75, 288-292, https://doi.org/10.1093/jaoac/75.2.288.

26. Bergman, I.; Loxley, R. Two improved and simplified methods for the spectrophotometric determinations of hydroxy-proline. Analytical Chemistry, 1963, 35, 1967 - 1970. https://doi.org/10.1021/ac60205a053.

27. Hill, F. The solubility of intermuscular collagen in meat animals of various ages. Journal of Food Science, 1966, 31,161 - 166. https://doi.org/10.1111/j.1365-2621.1966.tb00472.x.

28. Boccard, R.L.; Naudé, R.T.; Cronje, D.E.; Smit, M.; Venter, H.J.; Rossouw, E. The influence of age, sex and breed of cattle on their muscle characteristics. Meat science, 1979, 3, 261 - 280. https://doi.org/10.1016/0309-1740(79)90003-2.

29. Cross, H.R.; Carpenter, Z.L.; Smith, G.C. Effects of intramuscular collagen and elastin on bovine muscle tenderness. Journal of Food Science, 1973, 38, 998 - 1003. https://doi.org/10.1111/j.1365-2621.1973.tb02133.x.

30. Colorimetry (CIE). CIE publ. no. (Second Ed.). Vienna, 1986. Commission International de I'Eclairage

31. Krzywicki K. Assessment of relative content of myoglobin oxymyoglobin and metmyoglobin at the surface of beef. Meat Science, 1978, 3, 1 - 10. https://doi.org/10.1016/0309-1740(79)90019-6.

32. MacDougall, D. B. Colour in meat. In G. G. Birch, J. G. Brennan., K. Parker (Eds.), Sensory properties of foods, Applied Science Publishers, London, 1977, pp. 59.

33. Young, O. A.; Priolo, A.; Simmons, N. J.; West, J. Effects of rigor attainment temperature on meat blooming and colour on display. Meat Science, 1999, 52, 47 - 56. https://doi.org/10.1016/S0309-1740(98)00147-8.

34. SAS/STAT User's Guide, Version 9, 1st printing, Volume 2. SAS Institute Incorporated, SAS Campus Drive, Cary, North Carolina, 1999, 27513.

35. Snedecor, G.W.; Cochran, W.G. Statistical methods, 7th Edition, Times. Iowa state University press, 1980.

36. Shapiro, S. S.; Wilk, M.B. An analysis of variance test for normality (complete samples). Biometrika, 1965, 52,591 - 611. https://doi.org/10.2307/2333709..

37. Babiker, S.A.; El Khider, I.A.; Shafie, S.A. Chemical composition and quality attributes of goat meat and lamb. Meat Science, 1990, 28, 273 - 277. https://doi.org/10.1016/0309-1740(90)90041-4.

38. Dhanda, J. S.; Taylor, D.G.; Murray, P.J.; McCosker, J.E. The influence of goat genotype on the production of Capretto and Chevon carcasses. 2. Meat quality. Meat Science, 1999, 52, 363 - 367. https://doi.org/10.1016/S0309-1740(99)00015-7

39. Adeyemi, K.D.; Sazili, A.Q. Efficacy of carcass electrical stimulation in meat quality enhancement: A review. Asian-Australian Journal of Animal Science, 2014, 27, 3, 447 - 456. https://doi.org/10.5713/ajas.2013.13463

40. Safari, J.; Mushi, D.E.; Mtenga, L.A.; Kifaro, G.C.; Eik, L.O. Effects of concentrate supplementation on carcass and meat quality attributes of feedlot finished Small East African goats. Livestock Sciences, 2009, 125, 266 - 274.

41. Hogg, B.W.; Mercer, G.J.K.; Mortimer, B.J.; Kirton, A.H.; Duganzick, D.M. Carcass and meat quality attributes of commercial goats in New Zealand. Small Ruminant Research, 1992, 8, 243 - 256. https://doi.org/10.1016/0921-4488(92)90045-6.

42. Swan, J.E.; Esguerra, C.M.; Farouk, M.M. Some physical, chemical and sensory properties of chevon products from three New Zealand breeds. Small Ruminant Research, 1998, 28, 273 - 280. https://doi.org/10.1016/S0921-4488(97)00087-4.

43. Kannan, G.; Kouakou, B.; Gelaye, S. Colour changes reflecting myoglobin and lipid oxidation in chevon cuts during refrigerated display. Small Ruminant Research, 2001, 42, 67 - 75. https://doi.org/10.1016/S0921-4488(01)00232-2.

44. Mahgoub, O.; Khan, A.J.; Al-Maqbaly, R.S.; Al-Sabahi, J.N.; Anna-Malai, K.; Al-Sakry. N.M. Fatty acid composition of muscle and fat tissues of Omani Jebel Akhdar goats of different sexes and weights. Meat Science, 2002, 61, 381 - 387. https://doi/doi.org/10.1016/s0309-1740(01)00208-x.

45. Mahgoub, O.; Kadim, I.T.; Al-Saqry, N.M.; Al-Busaidi, R.M. Effect of body weight and sex on carcass tissue distribution in goats. Meat Science, 2004, 67, 577 - 585. https://doi.org/10.1016/j.meatsci.2003.12.011

46. Devendra, C.; Owen, J.E. Quantitative and qualitative aspects of meat production from goats. World Animal Review, 1983, 47, 19 -29 .

47. Shahrai, N.N.; Babji, A.S.; Maskat, M.Y.; Razali, A.F.; Yusop, S.M. Effects of marbling on physical and sensory characteristics of ribeye steaks from four different cattle breeds. Anim. Biosc. 2021, 34, 904-913, https://doi.org/10.5713/ajas.20.0201.

48. Carpenter, Z. L.; King, G. T. Tenderness of lamb rib chops. Food Technology, 1965, 19, 11, 102.

49. Corbin, C.H., O'Quinn T.G., Garmyn, A.J., Legako, J.F., Hunt, M.R., Dinh, T.T.N., Rathmann, R.J., Brooks,J.C.,Miller, M,F. Sensory evaluation of tender beef strip loin steaks of varying marbling levels and quality treatments, Meat Science, 2015, 100, 24-31.

50. Berry, B.W. Tenderness of beef loin steaks as influenced by marbling level, removal of subcutaneous fat, and cooking method. Journal of Animal Science, 1993, 71:2412-2419.doi: 10.2527/1993.7192412x

51. Purslow P.P. Contribution of collagen and connective tissue to cooked meat toughness; some paradigms reviewed. Meat Science. 2018, 144, 127-134. doi: 10.1016/j.meatsci.2018.03.026. Epub 2018 Mar 31

52. Neethling, N. E.; Suman, S.P.; Sigge, G.O.; Hoffman, LC. Muscle-specific colour stability of blesbok (Damaliscus pygargus phillipsi) meat. Meat Science, 2016, 119, 69 - 79. doi:10.1016/j.meatsci.2016.04.015.

53. Casey, N.H.; Webb, E.C. Managing goat production for meat quality. Small Ruminant Research, 2010, 89, 2,218 - 224. https://doi.org/10.1016/j.smallrumres.2009.12.047.

54. Simela, L.; Webb E.C.; Frylinck L. Effect of sex, age and pre-slaughter conditioning on pH, temperature, tenderness and colour of indigenous South African goats. South African Journal of Animal Science, 2004, 24, 1, 208 - 211. 
55. Gardener, G.E.; Kenny, L.; Milton, J.T.B.; Pethick, D.W. Glycogen metabolism and ultimate pH in Merino, first cross and second cross wether lambs as affected by stress before slaughter. Australian Journal of Agricultural Research, 1999, 50, 175 - 181. https://doi.org/10.1071/A98093.

56. Seideman, S.C.; Cross, H.R.; Oltjen, R.R.; Schanbacher, B.D. Utilization of the Intact Male for Red Meat Production: A Review, Journal of Animal Science, 1982, Volume 55, Issue 4, October, pp. 826 - 840, https://doi.org/10.2527/jas1982.554826x.

57. Monin, G.; Seller, P. Pork of low technological quality with normal rate of muscle $\mathrm{pH}$ fall in the immediate post-mortem period: the case of the Hampshire breed. Meat Science, 1985, 13, 49 - 63. https://doi.org/10.1016/S0309-1740(85)80004-8.

58. Scheffler, T.L.; Park, S.; Gerrard, D.E. Lessons to learn about post-mortem metabolism using AMPKy3R200Q mutation in the pig. Meat Science, 2011, 89, 244 - 250. https://doi.org/10.1016/j.meatsci.2011.04.030. 